\title{
1 Polymers and Biopolymers with Antiviral Activity: 2 Potential Applications for Improving Food Safety
}

3

4 (Review)

5 Walter Randazzo ${ }^{1,2}$, María José Fabra ${ }^{2}$, Irene Falcó ${ }^{1,2}$, Amparo López-Rubio $^{2}$, Gloria Sánchez ${ }^{2}$

$8{ }^{1}$ Department of Microbiology and Ecology, University of Valencia. Av. Dr. Moliner, 50. 46100

$9 \quad$ Burjassot. Valencia. Spain

$10{ }^{2}$ Department of Preservation and Food Safety Technologies, IATA-CSIC, Avda. Agustin 11 Escardino 7, 46980 Paterna, Valencia, Spain

14 Corresponding author: Gloria Sánchez. Department of Preservation and Food Safety 15 Technologies, Institute of Agrochemistry and Food Technology (IATA-CSIC). Av. Agustín 16 Escardino, 7. 46980 Paterna. Valencia. Spain.

17 Tel.: + 3496 3900022; Fax: + 3496 3939301; E-mail: gloriasanchez@iata.csic.es 


\section{Chapter titles}

1. Abstract

2. Introduction

3. Polymers and biopolymers as carriers of active compounds

4. Methodologies applied to assess the antiviral activity of polymeric and biopolymeric materials for food applications

a. New developments in the methodologies applied to assess the antiviral activity against $\mathrm{HuNoVs}$

5. Development of food-grade polymers and biopolymers with antiviral potential

a. Antiviral materials for food contact surfaces

i. Regulatory issues

b. Antiviral food packaging materials

i. Promising developments

c. Antiviral food coatings

d. Encapsulation of antiviral compounds

6. Final remarks 
$37 \quad$ List of abbreviations

$38 \quad$ AdV2

39 EDAX

40 EFSA

41 EGCG

42 ELISA

43 EMA

$44 \quad$ FCV

$45 \quad$ FDA

$46 \quad$ FFS

47 GRAS

$48 \quad$ GSE

49 GTE

50 HAV

51 HEV

52 HIV-1

$53 \mathrm{HuNoV}$

$54 \quad \mathrm{MHC}$

$55 \mathrm{MNV}$

$56 \quad \mathrm{Mw}$

$57 \quad \mathrm{NP}$

58 PHA

59 PHBV

60 PGM

$61 \quad$ PLA

62 PMA

$63 \quad$ PP
Adenovirus serotype 2

Energy dispersive analysis of X-rays

European Food Safety Authority

Epigallocatechin gallate

Enzyme-linked immunosorbent assay

Ethidium monoazide

Feline calicivirus

Food and Drug Administration

Film-forming solutions

Generally recognized as safe

Grape seed extract

Green tea extract

Hepatitis A virus

Hepatitis E virus

Human immunodeficiency virus

Human norovirus

Micrometer-sized magnetic hybrid colloid

Murine norovirus

Molecular weight

Nanoparticle

Polyhydroxyalkanoate

Hydroxybutyrate-co-3-hydroxyvalerate

Porcine gastric mucin

Polylactic acid

Propidium monoazide

Polypropylene 
$64 \mathrm{RH}$

65 RTE

66 SEM

$67 \quad \mathrm{TCID}_{50}$

$68 \mathrm{TV}$
Relative humidity

Ready-to-eat

Scanning electron microscopy

Tissue culture infectious dose 50

Tulane virus 


\section{Abstract}

70 Gastroenteritis and hepatitis, caused by human noroviruses (HuNoVs) and hepatitis A 71 virus (HAV), respectively, are the most common illnesses resulting from the consumption of food contaminated with human enteric viruses. Food-grade polymers can be tailor designed to improve food safety, either as novel food-packaging materials imparting active antimicrobial properties, applied in food contact surfaces to avoid cross-contamination, or as edible coatings to increase fresh produce's shelf life. The

76 incorporation of antimicrobial agents into food-grade polymers can be used to control 77 the food microbiota and even target specific foodborne pathogens to improve microbiological food safety and to enhance food quality. Enteric viruses are responsible for one fifth of acute gastroenteritis cases worldwide and the development of food-grade polymers and biopolymers with antiviral activity for food applications is a topic of

81 increased interest, both for academia and the food industry, even though developments are still limited. This review compiles existing studies in this widely unexplored area and highlights the potential of these developments to improve viral food safety.

84 


\section{Introduction}

Foodborne pathogens are a matter of increasing concern for consumers, industries and public institutions (WHO, 2015). Food, in fact, represents a vehicle of disease transmission caused by a wide range of pathogenic microorganisms, most notably pathogenic bacteria and enteric viruses (EFSA, 2016). Despite accounting for the major causes of foodborne outbreaks in high-income countries (EFSA, 2015; Shah et al., 2017), human enteric viruses have received comparatively less attention than other foodborne pathogens, such as Salmonella, Listeria, Escherichia coli, or Campylobacter. To date, almost 150 different types of human enteric viruses are known, which cause a variety of illnesses in humans, mainly gastroenteritis (such as human noroviruses (HuNoVs), sapoviruses, rotavirus, and astroviruses). They may also cause diverse additional disorders, such as hepatitis caused by hepatitis A virus (HAV) and hepatitis E virus (HEV), poliomyelitis (poliovirus), or meningitis (enteroviruses), even if reported to a lesser extent. In addition, they confer a high risk of morbidity and mortality in vulnerable populations, such as immunocompromised patients, children, the elderly and pregnant women (Rodríguez-Lázaro et al., 2012). Among them, HuNoVs and HAV have been determined to be the viruses of greatest concern from a food safety perspective (EFSA, 2016). Additionally, HEV has recently been identified as an emerging pathogen in Europe due to its potential for zoonotic transmission through the consumption of pork meat products (EFSA, 2011a, 2017).

Globally, foodborne hazards cause approximately 600 million illnesses annually, mainly due to infectious agents causing diarrheal diseases (550 million), with HuNoVs being responsible for 120 million cases attributed to water and food (WHO, 2015). Although the incidence rate of HAV infection has been on the decline in high-income countries, in part due to immunization availability, high-profile outbreaks continue to be reported, 
112 with 14 million cases and over 28,000 deaths attributed to food and waterborne hepatitis

113 A worldwide every year (WHO, 2015).

114 Since these viral pathogens are mainly transmitted by the fecal-oral route, contaminated 115 food products, such as shellfish, leafy greens, and berries, are the main food products 116 associated with viral foodborne outbreaks. Contamination by food handlers or cross117 contamination through contaminated surfaces is mainly associated with ready-to-eat 118 products, such as salads and, bakery or delicatessen items, which are prepared or 119 handled raw or after the foods have been cooked. Contamination can also occur during production, as for shellfish, usually harvested from waters affected by the discharge of treated and untreated sewage (McLeod, Polo, Le Saux, \& Le Guyader, 2017; Nappier, 122 Graczyk, \& Schwab, 2008) or berries and leafy greens, contaminated in the fields by pickers or through polluted irrigation waters (Le Guyader et al., 2004; López-Gálvez et al., 2016; Randazzo, López-Gálvez, Allende, Aznar, \& Sánchez, 2016), posing a higher health risk because both foodstuffs are frequently eaten raw (Ethelberg et al., 2010). For HuNoV outbreaks, shellfish represents the most commonly identified food vehicle in 127 Europe (EFSA, 2016), while leafy greens and fruits are the most frequently associated 128 foods in the United States (Hall, Wikswo, Pringle, Gould, \& Parashar, 2014). In addition, different studies have reported the transfer of viruses from the environment to foods during preparation and handling (Kotwal \& Cannon, 2014; Rönnqvist et al., 2014). In this sense, it is worth to report that recently a standard method has been established for the quantification of HAV and HuNoVs in several foodstuffs (soft fruit, 133 leaf, stem and bulb vegetables, bottled water, bivalve molluscan shellfish) or food surfaces. The specifications include concentration procedures, RNA extraction and target sequences to be detected by RT-qPCR (ISO 15216-1:2017, 2017). 
136 The low infectious dose of most human enteric viruses (Atmar et al., 2014; Teunis et al.,

137 2008), together with their high stability in the environment, make them extremely 138 infectious and highly transmissible. As non-enveloped viruses, human enteric viruses 139 tend to be more resistant to inactivation than foodborne bacteria to commonly used food 140 manufacturing processes (Sánchez, 2015). Overall, mild food manufacturing processes 141 show only marginal effects on the viral load, but when the processes are combined, the synergistic effects may enhance the level of human enteric virus inactivation (Kim, Lee, Kim, \& Park, 2015; Seo, Lee, Lim, \& Ko, 2012). An interesting future approach might be research into the effect of combining food processes on human enteric viruses. In such a scenario, although the prevention of viral contamination by good hygienic, agricultural, and manufacturing practices remains the main strategy in pursuit (Codex

147 Alimentarius, 2012), the use of polymers and biopolymers to develop antiviral materials with potential in food applications is envisaged as a promising alternative, which could help to avoid cross and/or recontaminations in line with the principles of the hurdle technology.

When browsing the extensive literature on antimicrobial materials, it is clear that biomedical applications dominate over food applications. In the food field, active packaging is an innovative solution to meet the consumer demands of fresh ready-to-eat food products together with the market trends of current food global trade, as it extends the shelf life and improves the safety of the food (López-Rubio et al., 2004). Many studies have successfully used active packaging to control foodborne pathogenic bacteria by applying of different antimicrobials, such as metals, chemicals, different essential oils, enzymes, and bacteriocins (Brandelli, Brum, \& dos Santos, 2017; 
packaging materials with antimicrobial activity are commercially available, such as Zeomic $^{\mathrm{TM}}$, AgIon ${ }^{\mathrm{TM}}$, Novaron ${ }^{\mathrm{TM}}$ and Cleanaid ${ }^{\mathrm{TM}}$ (Sung et al., 2013).

Despite the extensive research carried out to evaluate the efficacy of antimicrobial packaging on foodborne pathogenic bacteria (Brandelli et al., 2017; Maisanaba et al., 2017; Sardarodiyan \& Mahdian, 2016) and molds (Nguyen Van Long, Joly, \& Dantigny, 2016), only limited information is available for their use against human enteric viruses (Table 1).

This review analyzes the published literature on the current state of knowledge regarding the development of polymers and biopolymers with antiviral activity for food applications and the future perspectives of their application to enhance microbial food safety.

\section{$\underline{\text { Polymers and biopolymers as carriers of active compounds }}$}

In the last decades, the study of polymers of interest for food-related applications has mainly aimed at improving the technological performance of packaging materials to extend the shelf life of the food products and improve food safety. However, their use has been customized providing them an active role for inhibiting the growth of spoilage and pathogenic foodborne bacteria and, more recently, of human enteric viruses, thus imparting antibacterial and antiviral properties of interest for food safety purposes. This can be achieved by temporarily trapping biocidal substances within the polymer ( $\mathrm{Su}$ et al., 2015) or by covalent bonding (Thomassin, Lenoir, Riga, Jerome, \& Detrembleur, 2007). In such a context, the stability and/or release of the active compounds incorporated, which is based on their interactions with the polymeric material and on the environmental conditions of its application $(\mathrm{pH}$, temperature, relative humidity, etc.), are key for guaranteeing their efficacy. 
184 The large variety of materials and compositions available and the possibility of blending, chemically modifying them, or using nanotechnology tools to improve their performance have made polymers and biopolymers the materials of choice as carriers of active compounds for this type of application (López-Rubio, Gavara, \& Lagaron, 2006). Albeit there are several factors that may affect the stability and/or release kinetics, including the inherent characteristics of the active compounds to be incorporated (such as molecular weight, polarity, or initial concentration) (Hu, Chen, \& Wang, 2012; Suppakul, Sonneveld, Bigger, \& Miltz, 2011), the chemical composition of the packaged food product (Gherardi, Becerril, Nerin, \& Bosetti, 2016; Han, Castell-Perez, \& Moreira, 2008), or the ambient conditions (Chalier, Ben Arfa, Guillard, \& Gontard, 2009; Chen, Wang, Hu, \& Wang, 2012; Han et al., 2008; Kurek, Guinault, Voilley, Galić, \& Debeaufort, 2014), the polymeric/biopolymeric materials themselves play a key role in the design of novel antiviral materials.

Several factors need to be considered when designing materials with antiviral properties. The main one is the intended application of this material, as synthetic and bio-based plastics like polypropylene (PP) or polyhydroxyalkanoates (PHAs) may be used if the material is to be used as a food contact surface or food-packaging material, while natural biopolymers like polysaccharides (starch, chitosan, cellulose, etc.), proteins (soy protein, zein, etc.) and lipids (such as beeswax) with "generally recognized as safe" (GRAS) status should be selected for applications as edible coatings on fresh food products.

The most relevant factors to be considered for material selection and design can be divided into the following:

(i) Intrinsic material characteristics: these include the chemical composition and polarity (which will determine their compatibility with the active 
compounds) and molecular weight (Mw), which is not usually considered but it has been reported to affect release properties (Fernández-Pan, Maté, Gardrat, \& Coma, 2015; Lavin, Zhang, Furtado, Hopkins, \& Mathiowitz, 2013).

(ii) Processing conditions: the processing conditions used for material development will have a direct impact on several relevant properties, such as crystallinity, thermal properties, thickness, or porosity. All these factors will affect the stability and/or release properties of the biocidal compounds incorporated although very few studies exist to date that take them into account (Efrati et al., 2014).

All the knowledge gained from the large number of existing studies on antimicrobial polymers can be leveraged for the development of antiviral materials for food applications, through the incorporation of compounds with proven antiviral properties within the polymeric/biopolymeric structures. However, it should be mentioned that the practical application of these materials as effective biocidal carriers in the food industry has been limited for many reasons, including the degradation of the bioactive agents, or their quick release from the materials (Campos, Gerschenson, \& Flores, 2011). This again denotes the need to understand how the structural characteristics of the materials developed affect both the stability and release (if the substances are not immobilized) of the active compounds.

Although in the following sections specific examples about the strategies followed for the development of different types of antiviral materials are given, a general trend in this area is related to taking advantage of the inherent characteristics of different biopolymers to foster their interactions with the active compounds to control the release properties (Mascheroni, Capretti, Limbo, \& Piergiovanni, 2012; Tawakkal, Cran, \& 
234 Bigger, 2016). Processing methods have also been adapted to improve biocidal activity

235 making use of nanotechnology tools, either to protect the bioactive compounds, through

236 micro- or nanoencapsulation (Gómez-Mascaraque, Sánchez, \& Lopez-Rubio, 2016), or

237 to develop multilayered/nanolaminate delivery systems with improved performance

238 (Aloui \& Khwaldia, 2016; Castro-Mayorga et al., 2017). In the specific case of edible

239 coatings for fresh food products, nanoemulsions are being implemented, as they can be

240 formulated with natural food-grade ingredients and their production process is easily

241 scalable in the industry by high-pressure homogenization process (Donsì, Annunziata,

242 Sessa, \& Ferrari, 2011). The layer-by-layer methodology has also received great interest

243 as a new tool to create multilayer nanocoatings to extend the shelf life of perishable

244 foods (Fabra, Flores-López, et al., 2016; Mantilla, Castell-Perez, Gomes, \& Moreira,

245 2013; Moreira et al., 2014; Sipahi, Castell-Perez, Moreira, Gomes, \& Castillo, 2013).

246 Recent developments in active food packaging include the use of active labels, surface

247 modification, or incorporation of the biocide agents either included in coatings or in the

248 adhesives of multilayer structures (Akrami et al., 2015; Gherardi et al., 2016; Han et al.,

249 2008; Narayanan, Neera, Mallesha, \& Ramana, 2013; Otero et al., 2014). These systems

250 can be used as a starting point for the implementation of food materials with antiviral

251 properties.

Methodologies applied to assess the antiviral activity of polymeric and

\section{3 biopolymeric materials for food applications}

254 Most studies to determine the antiviral activity of polymeric and biopolymeric materials

255 have been performed by artificially adding a known amount of a virus to a given 256 material, determining the reduction in the infectious titer after subjecting the spiked

257 material to designated conditions and applying statistical procedures to determine the 258 significance of virus decay (Fig. 1). Evidently, this implies the use of virus strains that 
can be propagated in cell culture and enumerated through infectivity, thus greatly restricting the range of strains that are able to be included in these studies due to the difficulties in developing in vitro cultivation systems to replicate the most relevant human enteric viruses, such as HuNoV or wild-type HAV strains. Virus detection by cell culture is mainly based on the formation of cytopathic effects, followed by the quantification of the viruses by plaque assay, the most probable number, or tissue culture infectious dose $50\left(\mathrm{TCID}_{50}\right)$. In this sense, a promising in vitro cultivation system for HuNoVs using stem cell-derived human enteroids has been recently developed, but there are limitations that need to be overcome before it can be routinely used (Ettayebi et al., 2016). Therefore, the infectivity of HuNoVs has been mainly inferred through cultivable surrogates, such as feline calicivirus (FCV), murine norovirus (MNV) and, more recently, Tulane virus (TV) (Hirneisen \& Kniel, 2013). Even though these animal viruses have largely been used to study the survival rate of HuNoVs exposed to different inactivation processes, the appropriateness of such surrogates as models still raises questions and need to be confirmed (Bae \& Schwab, 2008; NACMCF, 2016).

Additionally, the wide range of applications of antiviral materials hampers the development of a standard methodology. To date, the absence of a specific and official regulation to evaluate the antiviral activity of active polymeric materials for food applications makes it difficult to compare the results of the assays of different studies. To overcome this lack, standard protocols developed for bacteria are often modified and adjusted to the purposes and circumstances of the antiviral assessment (Fig. 1). In fact, the antiviral experimental trials commonly apply well-established procedures aimed to assess the antimicrobial activity on plastics, and other non-porous surfaces, against bacteria and molds, such as the ISO 22196:2011 and the Japanese Industrial Standard 
JIS Z 2801:2000 (Castro-Mayorga et al., 2017; Fabra, Castro-Mayorga, et al., 2016;

Martínez-Abad, Ocio, Lagarón, \& Sánchez, 2013). Other protocols have been also applied that differ in the inoculation, exposure, and recovery techniques adopted. For example, Amankwaah (2013) determined the virucidal activity of GTE films by placing them in the bottom of 6 -well plates and filling the well with the virus suspension. After exposure, virus suspensions were recovered and titrated (Amankwaah, 2013; Haldar, An, Álvarez de Cienfuegos, Chen, \& Klibanov, 2006). Similarly, Warnes and Keevil (2013) applied a previously proposed protocol optimized for bacteria (Warnes, Green, Michels, \& Keevil, 2010) to assess the antiviral activity of copper coupons. In this work, virus recovery was performed with the help of glass beads, commonly used for bacteria.

As a general procedure applied for antiviral polymeric materials, the evaluation considers a viral inoculation step onto the material, a waiting/contact time while the active compound in the polymeric material exerts its expected antiviral activity, and, finally, a recovery step with a neutralizer solution to stop the inhibiting action or by swabbing (Bright, Sicairos-Ruelas, Gundy, \& Gerba, 2008; Martínez-Abad et al., 2013). For comparative purposes, control materials must be prepared without the active compound and tested under the same experimental conditions to rule out the intrinsic antiviral activity of the polymers/biopolymers, as described for chitosan (Amankwaah, 2013; Davis, Zivanovic, D'Souza, \& Davidson, 2012). Thus, the antiviral activity of the tested polymers is estimated by comparing the number of infectious viruses on the polymers containing active compounds and the polymers without the active compound at specific experimental conditions (normally, contact time and temperature). This approach cannot be used in the case of coatings, where the gel nature of the biopolymers normally employed complicates the assessment using the procedures applied for solid 
309 (e.g., films) materials. To overcome this limitation, our group successfully adapted the 310 ISO 14476:2013 (ISO 14476:2013, 2013) to test the antiviral activity of polymer gels. 311 Specifically, pieces of each edible film $(25 \pm 5 \mathrm{mg})$ were inoculated with virus suspensions diluted in PBS and samples were incubated overnight at $37^{\circ} \mathrm{C}$. Then, the effect of the active polymer gels was neutralized, and viruses were titrated in the corresponding cell line (Fabra, Falcó, Randazzo, Sánchez, \& López, in press).

Thus, many parameters could differ among the different procedures, and they should be reported and clearly specified in the final report displaying the results. Amongst them, the main factors to be considered are: (i) the specifications of the active compound (such as the composition and relative concentrations) and how it has been incorporated within the polymeric material, (ii) the possible cytotoxicity effect against the tested cell lines, (iii) the effect of the neutralizer solution, (iv) the effect of working conditions tested (clean or dirty conditions), (v) temperature and humidity, (vi) the contact time with the active polymeric material, and (vii) the technique adopted for the virus recovery. As an example, while dirt conditions affect the disinfectant efficiency of antiviral solutions in surfaces ( $\mathrm{Li}$, Baert, \& Uyttendaele, 2013), for food-packaging applications this parameter loses its importance, as the food matrix characteristics are the variables to be evaluated. Indeed, the assessment of the effectiveness of the antiviral materials for a specific food application could reflect important information for its final use under real conditions. In fact, it is known that food matrices might interfere with the antiviral activity of several compounds (Li et al., 2012; Sánchez, Aznar, \& Sánchez, 2015), limiting its inactivation effect. Therefore, generally, greater amounts of active compounds need to be used in real conditions to get the same effect as in the in vitro tests (Goyal \& Cannon, 2016). In this sense, some concerns have arisen due to the correlation between such high reported log reduction in laboratory tests and the real 
decrease in the risk associated with foodborne viral transmission (Goyal \& Cannon, 2016). For instance, reduced antiviral activity was observed when silver nanoparticles incorporated in coupons were used in surface waters, likely due to the interaction between silver nanoparticles with nonspecific particles in the highly turbid surface waters (Park et al., 2014).

\section{New developments in the methodologies applied to assess the antiviral activity} against HuNoVs

Apart from using cultivable surrogates, different methodologies to assess the antiviral activity of some compounds against HuNoVs have been reported (DiCaprio, 2017) (Fig. 1), such as:

(i) Using the HuNoV's ability to bind saliva or porcine gastric mucin (PGM) (Tan \& Jiang, 2005; Tang et al., 2010), which allows for the selective recovery of potentially infectious HuNoVs (Dancho, Chen, \& Kingsley, 2012; DiCaprio et al., 2016). Saliva and PGM contain multiple human histoblood group antigens that have been recognized as receptors or co-receptors for HuNoVs (Tian, Brandi, \& Mandrell, 2005). Currently, PGM and salivabinding enzyme-linked immunosorbent assays (ELISA) have been used to evaluate the antiviral activity of grape seed extract (GSE) (Li et al., 2012) and green tea extract (GTE) (Falcó et al., under review) against HuNoVs and virus-like particles (VLPs) of HuNoVs.

(ii) Using VLPs of HuNoVs, which are expressed in baculovirus-infected insect cells and have the same morphological, antigenic, and glycan-binding properties as HuNoVs. Furthermore, the protruding $(\mathrm{P})$ domain of the major structural protein of HuNoV capsid VP1 forms subviral particles, the P 
particles (Carmona-Vicente, Allen, Rodríguez-Díaz, Iturriza-Gómara, \& Buesa, 2016; Carmona-Vicente, Vila-Vicent, et al., 2016). Both VLPs and P particles have been used to investigate the effects of GSE and GTE by ELISA and electron microscopy (Falcó et al., under review; Li et al., 2012).

(iii) Using HuNoV suspensions pretreated with nucleic acid intercalating dyes, such as conventional intercalating dyes (i.e. propidium monoazide, PMA, and ethidium monoazide, EMA) and newly developed ones (i.e., PMAxx, and PEMAX) (Elizaquível, Aznar, \& Sánchez, 2014; Randazzo, LópezGálvez, et al., 2016). This approach is based on the ability of intercalating dyes to penetrate only damaged or altered capsids and intercalate covalently into a viral genome after exposure to strong visible light, thus interfering with PCR amplification. Thus far, the inactivation of HuNoV GI and GII with epigallocatechin gallate, a natural compound, has been investigated by PMAxx-Triton pretreatment (Falcó et al., 2017).

\section{Development of food-grade polymers and biopolymers with antiviral potential}

Antimicrobial-packaging applications are directly related to food safety as well as to shelf life extension by preventing the growth of spoilage or pathogenic microorganisms. With this aim, biopolymer matrices can serve as an excellent carrier of antimicrobial agents, as noted in the above section. In fact, several works have been carried out in the last several decades concerning the antimicrobial efficacy of essential oils, natural extracts, and bacteriocins incorporated into biopolymer matrices (Cardoso et al., 2017; Honarvar et al., 2017; Moghimi, Aliahmadi, \& Rafati, 2017; Rezaeigolestani et al., 2017). Nevertheless, although their bactericide and fungicide properties have been largely studied, little information exists in the literature about how biopolymers could 
act as carriers of virucide compounds and how they behave in a food package or edible coating. Thus, biopolymers can serve as an excellent vehicle of antiviral compounds in many fields within the food area, such as food packaging, food contact surfaces, and edible coatings.

Natural extracts (e.g., GTE, GSE.), essential oils, or their main compounds (e.g., carvacrol, cinnamaldehyde) and nanometals (e.g., silver, copper) with demonstrated virucidal activity can be postulated as potential candidates to develop antiviral biopolymers (D'Souza, 2014; Li et al., 2013; Ryu et al., 2015).

The development of new packaging functionalities (i.e., antiviral) is possible because the processing equipment and conditions are the same as those currently being used (casting, melt-compounding) for other applications. Nonetheless, the effectiveness of the antiviral compounds could even be increased by developing multilayer structures (Fabra, Castro-Mayorga, et al., 2016), encapsulating the active compound (GómezMascaraque et al., 2016) with potential application on shellfish depuration (McLeod et al., 2017), or even modifying the biopolymer surface to increase the antiviral activity. More detailed information about the potential and specific areas of interest will be detailed below (Fig. 2).

\section{Antiviral materials for food contact surfaces}

Even if human enteric viruses are primarily transmitted through direct contact personto-person, or through contaminated water or food (de Graaf, van Beek, \& Koopmans, 2016; Sánchez, 2015), an increasing number of outbreaks in developed countries originated from cross-contaminated surfaces (fomites). In fact, their low infectious dose (Teunis et al., 2008), prolonged stability in the environment, and resistance to chemical inactivation (Cheesbrough, Green, Gallimore, Wright, \& Brown, 2000; Kuusi et al., 2002), make human enteric viruses highly transmissible through environmental fomites, 
409 including food contact surfaces. Common areas and facilities, e.g., hospitals, cruise 410 ships, restaurants, and communal kitchens, represent exposure sites with a high health 411 risk associated with viral outbreaks (EFSA, 2016; Hall et al., 2014; Hedlund, Rubilar412 Abreu, \& Svensson, 2000). Both non-porous (aluminum, china, glazed tile, glass, latex, 413 plastic, polystyrene, and stainless steel) and porous (cloth, different types of papers, and 414 cotton cloth) surfaces have been reported to harbor enteric viruses (Abad et al., 2001; 415 Boone \& Gerba, 2007). Thus, different guidelines have been proposed to limit and 416 control the occurrence of pathogens on food products by increasing hygienic measures 417 along the entire food chain (Codex Alimentarius, 2012; WHO, 2015). Specifically, for 418 food industries and food handling services, it is extremely important to control the viral 419 contamination of surfaces, both in food-processing lines and in manipulation counters.

420 For food contact surfaces, the ideal material should exert its antiviral activity throughout its use. Therefore, the polymeric material should act by direct contact and not by migration of the active compounds, as is normally the case for most natural compounds. Another aspect to consider when selecting the material to be used is that it must be nontoxic and designed to withstand the environment of their intended use and the action of food. Moreover, a smooth and non-porous surface is preferable to avoid the presence of bacterial and/or viral reservoir niches. Additional features should be the material's ease of cleaning and washing and its resistance to chemical detergents. The first attempt to develop antiviral materials for food contact surfaces was successfully carried out by Martínez-Abad and collaborators (Martínez-Abad et al., 2013). Specifically, the authors applied silver-infused polylactide films for the inactivation of FCV and tested their antiviral performance in food application. The active renewable food- packaging material based on polylactic acid (PLA) incorporating silver ions (from 0.1 to $10 \mathrm{~g} / \mathrm{Kg}$ ) was obtained by a solvent casting technique, and its 
antimicrobial efficacy was evaluated by using the JIS Z 2801 standard (Japanese

435 Standards Association, 2012). The antiviral activity of silver-PLA films was dosedependent, where increasing concentrations of silver showed increased reduction in viral titers. FCV, often reported as the most sensitive HuNoV surrogate compared to others, such as MNV or Tulane virus, was less susceptible than Salmonella, suggesting a higher resistance of viruses to antimicrobial compounds than bacteria (Russell, 2003). In particular, reductions of approximately 2 and more than $4.4 \log \mathrm{TCID}_{50} / \mathrm{mL}$ were shown by 0.1 and $1 \%$ of silver-PLA films after $24 \mathrm{~h}$ contact, respectively, while for Salmonella, reductions of more than $6 \log \mathrm{CFU} / \mathrm{mL}$ were reported under the same experimental conditions (Martínez-Abad et al., 2013). The authors also demonstrated that after consecutive washings of the silver-PLA material, it efficiently kept its antiviral activity, thus providing a long-lasting antiviral effect, highlighting its suitability for use as food contact surfaces.

Another attempt to develop antiviral surfaces was made by Park et al. (2014), who developed a novel micrometer-sized magnetic hybrid colloid (MHC) activated with variously sized AgNPs and evaluated its efficacy for inactivating bacteriophage $\varphi$ X174, MNV, and adenovirus serotype 2 (AdV2). The infectivity of phage $\varphi$ X174 and MNV was reduced by more than $2 \log$ after exposure to $4.6 \times 10^{9} \mathrm{Ag} 30-\mathrm{MHCs} / \mathrm{mL}$ (silver content $400 \mathrm{ppm}$ ) for $1 \mathrm{~h}$ at $25^{\circ} \mathrm{C}$ while in a previous study Escherichia coli reductions of more than $6 \log \mathrm{CFU} / \mathrm{mL}$ were reported (Park, Park, Ko, \& Woo, 2013).

454 Since it is of particular interest to develop active surfaces with enhanced virucidal 455 activity at lower loadings due to legislative restrictions, Castro-Mayorga et al. (2017) 456 have recently developed novel routes to guarantee the dispersion and stability of silver nanoparticles (AgNPs) in biopolymer matrices. Furthermore, the effect that the stabilized AgNPs had on transparency and mechanical properties was negligible due to 
459 the low AgNPs loadings. Concretely, they applied poly (3-hydroxybutyrate-co-3-

460 hydroxyvalerate) (PHBV) materials enriched with AgNP to inactivate $\mathrm{HuNoV}$

461 surrogates, FCV and MNV. Interestingly, the active surface was obtained by depositing

462 a coating of thermally post-processed electrospun PHBV18 (18\% mol valerate)/AgNP

463 fiber mats over compression molded PHBV3 (3\% mol valerate) films, showing

464 excellent antimicrobial properties even at $0.027 \%$. Moreover, the homogeneous

465 distribution of AgNP into the coating and onto the PHBV3/PHBV18 layer was

466 confirmed by scanning electron microscopy (SEM) and energy dispersive analysis of X-

467 rays (EDAX) analysis. The antiviral activity of AgNP materials, tested by adapting the

468 ISO 22196:2011 norm (ISO 22196:2011), showed complete inactivation for FCV only,

469 following $24 \mathrm{~h}$ exposure at $37{ }^{\circ} \mathrm{C}$ and $100 \% \mathrm{RH}$. In the same conditions, MNV

470 infectivity was reduced by only $0.86 \log$ (Castro-Mayorga et al., 2017) and no viable

471 counts of Salmonella enterica and Listeria monocytogenes were recorded (Castro-

472 Mayorga, Fabra, \& Lagaron, 2016).

473 A different antiviral material (plastic coupons based on zeolites containing silver/copper

474 ions) was evaluated by Bright et al. (2008), who reported its effectiveness against feline

475 infectious peritonitis virus and FCV. Zeolites (sodium aluminosilicate) are porous

476 minerals that can be activated with metal ions, exchanging those for other cations

477 present in the environment, finally resulting in an interesting progressive release of the

478 active compounds. The antiviral effectiveness of zeolites activated with silver/copper

479 ions and incorporated into plastic coupons was evaluated by recovering the target virus

480 from the active surface by a swabbing procedure. Bright et al. (2008) reported more

481 than a $5 \log$ reduction for FCV infectivity after $24 \mathrm{~h}$ at $23{ }^{\circ} \mathrm{C}$ on plastic coupons

482 impregnated with $10 \%$ zeolite powder containing $6.5 \%$ copper and $3.5 \%$ silver ions.

483 The silver amount into these coupons was approximately $3.5 \mathrm{ppm}$, and excluding the 
additional antiviral effect of copper (Warnes \& Keevil, 2013), such concentration resulted in a greater inactivation in comparison with the AgNP-containing material tested by Castro-Mayorga et al. (2017). However, although the reduction rates reported for FCV by Martínez-Abad et al. (2013) using silver-PLA materials ( $>4.4$ log) were greater than those reported by Castro-Mayorga et al. (2017) using AgNP-PHBV materials $(1.42 \mathrm{log})$ under the same experimental conditions $\left(24 \mathrm{~h}\right.$ at $25 \pm 1{ }^{\circ} \mathrm{C}, 100 \%$ $\mathrm{RH}$ ), the silver concentration within the polymer matrices was significantly different, 10 ppm and $0.27 \mathrm{ppm}$, respectively. Nevertheless, the specific surface of nanoparticles as well as the dispersion and stability of AgNPs in the polymer are key aspects that determine the antiviral activity of the active surfaces. However, although it could then be inferred that PHBV3/PHBV18/AgNP may have higher antiviral activity against FCV than the above-mentioned publications, further studies should evaluate the efficacy of such system in experiments mimicking real application conditions.

Studies evaluating copper antiviral activity incorporated into surfaces have been reported for several viruses. For example, Noyce, Michels, and Keevil (2007) reported that influenza A virus particles inoculated onto copper surfaces showed nearly a $4 \log$ decrease following $6 \mathrm{~h}$ of incubation at $22{ }^{\circ} \mathrm{C}$ at 50 to $60 \%$ relative humidity. Using a surrogate of HuNoV (Warnes \& Keevil, 2013; Warnes, Summersgill, \& Keevil, 2015), reported rapid $\mathrm{MNV}$ inactivation on dry copper and copper alloy $(60-80 \% \mathrm{Cu})$ surfaces, demonstrating that it was due to the loss of viral capsid integrity. Similarly, Manuel, Moore, and Jaykus (2015) evaluated the reduction of HuNoV genogroup II.4 exposed for 60 min to pure copper surface as $4 \log$ units by RT-qPCR, observing, in addition, a proportional reduction effect related to the percentage of copper in the alloys.

The antiviral effect of polymeric matrices containing copper has been also reported by Borkow and Gabbay (2004), who evaluated the antiviral efficacy of latex gloves 
509 containing copper that reduced human immunodeficiency virus (HIV-1) infectivity in a

510 dose-dependent manner (Borkow \& Gabbay, 2004).

511 The antiviral activity of glass coated with thin films of titanium dioxide $\left(\mathrm{TiO}_{2}\right)$, copper

512 oxide $(\mathrm{CuO})$, and hybrid $\mathrm{CuO} / \mathrm{TiO}_{2}$ prepared by atmospheric chemical vapour

513 deposition (Ap-CVD) was investigated by Ditta et al. (2008) using the inactivation of

514 bacteriophage T4 as a model for inactivation of enteric viruses. The inactivation rates

515 were reported to be higher by $\mathrm{CuO}$ and $\mathrm{CuO} / \mathrm{TiO}_{2}$, suggesting that photocatalysis and

516 toxicity of copper acted synergistically to inactivate bacteriophage T4.

517 Castro-Mayorga, Fabra Rovira, Cabedo Mas, Sánchez Moragas, and Lagarón Cabello

518 (2018) recently developed and characterized two active copper-based systems

519 performing interesting antiviral activity. In their study, the antiviral activity of

520 biodegradable PHBV melt mixed nanocomposites containing 0.1 and $0.05 \%$ of $\mathrm{CuO}$

521 was compared to bilayer structures consisting of a bottom layer of compression molded

522 PHBV3 (3\% mol valerate) coated with an active electrospun fibers layer made with

523 microbial mixed culture-derived PHBV18 (18\% valerate) and $\mathrm{CuO}$ nanoparticles

$524(0.05 \%)$. Remarkably, the antiviral assay carried out with MNV adapting the ISO

$52522196: 2011$ showed 1.83 and $3.19 \log \mathrm{TCID}_{50} / \mathrm{mL}$ reductions for 0.1 and $0.05 \%$ neat

526 PHBVs films, respectively, while no infectious viruses were recovered when in contact

527 with the coated structure for the same experimental conditions $\left(24 \mathrm{~h}\right.$ at $25{ }^{\circ} \mathrm{C}, 100 \%$

$528 \mathrm{RH})$. Therefore, it was demonstrated that by incorporating $\mathrm{CuO}$ into an electrospun

529 coating, the $\mathrm{CuO}$ loading could be reduced.

530 As reported for other antimicrobial materials, higher antibacterial activity against

531 Salmonella enterica and Listeria monocytogenes was recorded under the same

532 experimental conditions (Castro-Mayorga et al., 2018). 
533 Even if evidence of zinc virucidal activity has been reported against rhinoviruses

534 (Hulisz, 2004), respiratory syncytial virus (Suara \& Crowe, 2004), vaccinia virus (Katz 535 \& Margalith, 1981), herpes simplex virus (HSV) (Arens \& Travis, 2000), and HIV-1 536 (Haraguchi, Sakurai, Hussain, Anner, \& Hoshino, 1999), it has been scarcely 537 investigated against human enteric viruses either in suspension or applied into 538 materials. Some inference regarding its antiviral activity has been drawn for brass (zinc539 copper alloy) using MNV (Warnes et al., 2013). In particular, Warnes and Keevil 540 (2013) suggested that zinc did have some antiviral effect, which was synergistic with 541 copper and resulted in an increased efficacy of brasses with lower percentages of 542 copper.

543 To date, the antiviral activity of gold-based surfaces has not been reported, and the 544 elevated cost of this metal limits its application in food contact surfaces. Nevertheless, 545 Broglie et al. (2015) reported the rapid inactivation of $\mathrm{HuNoV}$ due to $\mathrm{Au} / \mathrm{CuS}$ core/shell 546 NPs evaluated on HuNoV GI.1 VLPs as a model viral system and using an absorbance 547 based ELISA.

$548 \quad$ Regulatory issues

549 Interestingly, the use of metal nanoparticles has attracted considerable attention, even 550 though nanotechnology is still out of most legislation frames. In this context, the 551 application of nanostructured materials demonstrated enhanced antimicrobial activity at 552 low concentrations due to the high surface-to-volume ratio, thus representing a 553 promising tool to improve the functionality of polymers used in antimicrobial food 554 antimicrobial food contact surfaces. In the last years, nanoparticles composed of metals, 555 metal oxides, metal salts, and metal hydroxides have been developed, the metal 556 nanoparticles of zinc oxide and silver being the most promising against both foodborne 
557 bacteria (Mauriello, 2016; Moritz \& Geszke-Moritz, 2013) and human enteric viruses

558 (Castro-Mayorga et al., 2017).

559 In the US, and especially in Japan, the use of silver zeolites and silver zirconium 560 phosphate resins is well established with several commercial brands incorporating silver 561 in textiles or as coatings in different products (Appendini \& Hotchkiss, 2002; 562 Quintavalla \& Vicini, 2002) with a maximum silver content of 3\%. However, in the 563 food area, only silver nitrate is regulated with a maximum limit of $0.017 \mathrm{mg} / \mathrm{kg}$ in 564 foodstuffs and $0.1 \mathrm{mg} / \mathrm{kg}$ for drinking waters (FDA, 2010). As far as nanosilver is 565 concerned, colloidal solutions are accepted in the US and commercialized as nutrition 566 supplements. In the EU, the EFSA provisionally accepts the use of silver in food contact 567 materials with a maximum of $5 \%$ silver in the form of silver zeolites or silver 568 zirconium phosphate glasses, and silver migration is restricted to a maximum 0.05 $569 \mathrm{mg} / \mathrm{kg}$ in food (EFSA, 2006) while $5 \mathrm{mg} \mathrm{Cu} / \mathrm{Kg}$ food is the permitted migration limit 570 established by the current EU regulation (European Commission, 2011) for a 571 hypothetical package surface of $6 \mathrm{dm}^{2} / \mathrm{Kg}$ food, although there is not a specific 572 regulation for NPs. As of now, the EU legislation requires a market authorization of 573 nanomaterial applications in foods based on a safety assessment by the EFSA of the 574 potential health risks that may be associated with nanomaterials in foods (EFSA, 575 2011b).

576

\section{Antiviral food packaging materials}

578 Currently, the increasing consumers' demand for fresh, minimally processed, and ready579 to-eat (RTE) products has challenged industries to extend the shelf life of food products 580 together with guaranteeing their safety. Furthermore, the changes in food production 581 (i.e., global trade) and food processing (i.e., cross-contamination) have posed novel 
582 risks that need to be controlled. As a result, food-packaging materials have been 583 developed with the aim of controlling pathogenic and spoilage bacteria, yeast, and 584 molds in food, exerting an inhibition of their growth (bacteriostatic activity) or a killing 585 effect (bactericidal activity) (Yildirim et al., 2018). In this sense, the physicochemical 586 properties of the polymer constituting the selective barrier to gas transport together with 587 the antimicrobial properties of different active compounds have been pointed out as key factors of a hurdle technology applied to extend foods' commercial shelf life. The use of biopolymers as food-packaging materials is of high interest given their excellent filmforming, non-toxic, odorless, tasteless, biodegradable, and edible properties. In the case of food-packaging materials with antiviral activity, the main goal is the inactivation of 592 human enteric viruses that may be present in the food due to contamination from both raw materials or during processing procedures.

594 To date, limited information is available concerning food-packaging materials specifically developed to control human enteric viruses (Table 1 and Fig. 2), and just one study evaluated its efficacy in food products (Martínez-Abad et al., 2013). In this 597 study, a silver-infused PLA material with antiviral activity was successfully manufactured and evaluated on lettuce and paprika (Martínez-Abad et al., 2013). Generally, the authors reported lower FCV inactivation when films were applied on food samples compared to food-contact surfaces, also showing variable results depending on the food type. In fact, $1 \%$ silver-PLA films eliminated the infectivity of 602 FCV in lettuce. Less silver amount $(0.1 \%)$ progressively reduced the FCV infectivity, achieving the complete inactivation only at the end of the storage time (6 days). On the contrary, silver-PLA films did not affect FCV infectivity on paprika, suggesting an interfering effect dependent on the food matrix. Additionally, silver-PLA films applied to food showed higher inactivation on Salmonella compared to FCV. 
607 The use of ions incorporated into packaging materials showed some drawbacks, as

608

609

610

611

612

613

614

615 physical or chemical factors may alter their properties resulting in compounds without antimicrobial activity (Castro-Mayorga et al., 2016; Ilg \& Kreyenschmidt, 2011). For instance, sulphides or other silver complexes may occur due to the exposure of silver ions to mid-high temperature, light, or UV, not only losing the antimicrobial activity, but also producing a strong brownish or blackish coloration of the material (Kasuga, Yoshikawa, Sakai, \& Nomiya, 2012), which finally limits its application for food packaging applications.

Apart from metals, several plant extracts have been incorporated into polymers with the idea of developing antiviral-packaging materials, even though these materials have not been evaluated in food matrices. For example, a pioneering study by Fabra, CastroMayorga, et al. (2016) evaluated the antiviral activity of a multilayer structure based on polyhydroxybutyrate (as outer layers) interlayed with electrospun zein fibers activated with cinnamaldehyde. In particular, the electrospinning process produced biodegradable multilayer structures by the application of electrostatic forces that draw polymer solutions or melts into ultrathin fibers, thus depositing them as mats of micro- or nanoscale fibers (Fabra, Busolo, Lopez-Rubio, \& Lagaron, 2013). This process overcomes the main drawback of typical technologies where high temperatures are needed to mold biodegradable polymers, a factor that limits their application for producing foodpackaging materials activated with thermally-sensitive compounds. This proof-ofconcept study developed a multilayer system activated with cinnamaldehyde $(2.60$ $\mathrm{mg} / \mathrm{cm}^{2}$ ) with antiviral activity against norovirus surrogates, but not for HAV. In particular, adapting the ISO 22196:2011, $2.75 \log \mathrm{TCID}_{50} / \mathrm{mL}$ reductions and complete inhibitions $\left(>2.48 \log \mathrm{TCID}_{50} / \mathrm{mL}\right)$ were reported for $\mathrm{MNV}$ and FCV after overnight treatment at $37{ }^{\circ} \mathrm{C}$ and $100 \% \mathrm{RH}$, respectively. Changes in temperature conditions 
632

633

634

635

636

637

638

639

640

641

642

643

644

645

646

647

648

649

650

651

652

653

654

655

656

resulted in significant reduced effectiveness of cinnamaldehyde multilayer systems, indicating that temperature is a major factor influencing the release or effectiveness of cinnamaldehyde, as previously reported for other natural compounds ( $\mathrm{Su} \& \mathrm{D}$ 'Souza, 2011).

Among the natural polysaccharides, chitosan showed strong antimicrobial, antifungal and antioxidative activities (Friedman \& Juneja, 2010; Seyfarth, Schliemann, Elsner, \& Hipler, 2008), together with excellent film- and coating-forming properties. As an example, the reduction or control of foodborne pathogenic bacteria could be enhanced by the addition to chitosan coating and films of natural active compounds, as essential oils (Randazzo, Jiménez-Belenguer, et al., 2016; Yuan, Chen, \& Li, 2016) or propolis (Torlak \& Sert, 2013) that act synergistically.

Although recently the antiviral properties of chitosan have been reported for virus suspensions (Chirkov, 2002; Davis et al., 2012; Davis, Zivanovic, Davidson, \& D'Souza, 2015; Su, Zivanovic, \& D'Souza, 2009), its antiviral activity when incorporated in food packaging remains poorly investigated. In Amankwaah's study (2013), chitosan did not enhance the antiviral activity of GTE and GSE in film-forming solutions (FFS) of either film. GTE and GSE were incorporated into chitosan films and tested against norovirus surrogates. Specifically, 1.60 and $4.50 \log$ PFU/mL reductions of MNV were obtained after $24 \mathrm{~h}$ contact with 5\% and 10\% GTE films, respectively. The film with the highest GTE concentration tested (15\%) reduced MNV infectivity to undetectable levels (Amankwaah, 2013). Similarly, MNV infectivity was reduced by 0.92, 1.89, and $2.27 \log \mathrm{PFU} / \mathrm{mL}$ after $4 \mathrm{~h}$ at $23{ }^{\circ} \mathrm{C}$ in contact with films with 5,10 , and $15 \%$ GSE, respectively. Higher reductions were recorded after $24 \mathrm{~h}$; the $15 \%$ GSE film completely inactivated MNV (more than 4 log) (Amankwaah, 2013).

Promising developments 
657 Although many other natural compounds have shown antiviral activity when tested in 658 vitro, their application into packaging materials to inactivate human enteric viruses still 659 remains unexplored. In fact, many of such compounds have been successfully tested 660 against food pathogenic bacteria and demonstrated antimicrobial activity also when 661 incorporated into food-packaging materials.

662 Of interest for future investigation to develop active antiviral materials are, for instance, 663 clove, oregano, and zataria essential oils, as they have demonstrated interesting antiviral 664 activity against norovirus surrogates (MNV and FCV) and HAV, as well as some main essential oil compounds, such as thymol and carvacrol (Elizaquível, Azizkhani, Aznar, \& Sánchez, 2013; Sánchez et al., 2015; Sánchez \& Aznar, 2015). Moreover, essential oils have demonstrated antimicrobial properties when incorporated into packaging films (Kashiri et al., 2017; Maisanaba et al., 2017; Randazzo, Jiménez-Belenguer, et al., 2016; Requena, Jiménez, Vargas, \& Chiralt, 2016) and antifungal activities (Mateo et al., 2017). Therefore, taking into account such encouraging findings, future research should investigate the antiviral performances of packaging films enriched with essential oils.

672 Furthermore, other natural plant-derived substances, such as aloe vera and Eriobotryae 673 folium extracts, showed antiviral activity against MNV (Ng et al., 2017) and could be 674 incorporated into food packaging materials in future studies. In the last years, many algal-derived products have been investigated, and some of the algal polysaccharides, like carrageenan, fucan, laminaran, and naviculan, are candidates

677 as natural antiviral agents in agricultural, biomedical, food, and pharmaceutical 678 applications (Ahmadi, Zorofchian Moghadamtousi, Abubakar, \& Zandi, 2015). For instance, HIV, papillomavirus, HSV, and influenza A virus have been successfully inactivated in vitro by carrageenan, a phycocolloid extracted from different red seaweed species (Pangestuti \& Kim, 2014). Moreover, recent studies developed active food- 
682 packaging films with antibacterial activity by including marine algal compounds (Luzi et al., 2017; Rodríguez-Martínez et al., 2016).

\section{Antiviral food coatings}

685 The growing consumer demand for minimally processed, easily prepared, and ready-toeat "fresh" food products with minimal chemical preservatives pose major challenges for food safety and quality. Different methods have been evaluated to eliminate or reduce human enteric viruses in food products, but many of the effective foodprocessing technologies cause physicochemical changes in foodstuffs (Sánchez, 2015). In contrast, edible films and coatings have been postulated as an emerging technology because their efficiency is based on the controlled release of the antimicrobials retained in the biopolymer matrix by optimizing and restricting additive doses. Edible films and coatings can be defined as food-grade emulsions based on polysaccharides, proteins, and lipids, which can be applied to most foodstuffs by spraying, spreading, or dipping, to enhance food quality, stability, and safety. The use of antimicrobial (bactericide, fungicide, and virucide) agents into edible films and coatings present several advantages, such as the dosage adjustment, cost reductions, and greater product adherences on the foodstuffs (Aloui \& Khwaldia, 2016; Dehghani, Hosseini, \& Regenstein, 2018).

There are many antimicrobial natural compounds with recognized bactericide, fungicide, or virucide activity than can be incorporated into edible films and coatings to reduce the risk of foodborne contamination and inhibit the development of spoilage microorganisms. The incorporation of natural extracts (i.e., polyphenol compounds) or essential oils having antimicrobial properties in edible films and coatings represent a new route to control microorganisms and foodborne pathogens transmitted through food to consumers. When selecting the active agent to be incorporated in an edible coating, 
707

708

709

710

711

712

713

714

715

716

717

718

719

720

721

722

723

724

725

726

727

728

729

730

not only its effectiveness against the target microorganism should be taken into account, but also its potential interactions with the hydrocolloid matrices and with the food components over which it will act (Sánchez-González, Cháfer, Hernández, Chiralt, \& González-Martínez, 2011).

There are several works in the literature reporting on the bactericide and fungicide properties of natural compounds incorporated into edible films and coatings (BermudezOria, Rodriguez-Gutierrez, Vioque, Rubio-Senent, \& Fernandez-Bolanos, 2017; Bosquez-Molina, Jesús, Bautista-Baños, Verde-Calvo, \& Morales-López, 2010; Guo, Yadav, \& Jin, 2017; Umagiliyage, Becerra-Mora, Kohli, Fisher, \& Choudhary, 2017; Umaraw \& Verma, 2017). However, to the best of our knowledge, there is no information about antiviral edible films and coatings. This new aspect could be of great interest, for instance, in minimally processed fruits and vegetables, which are obtaining increasing recognition as important vehicles for the transmission of human pathogens, including foodborne viruses (Lynch, Tauxe, \& Hedberg, 2009). Therefore, there is a need to develop new strategies, such as the development of edible coatings to improve the virological safety of these products.

In this regard, potential natural compounds with demonstrated antiviral activity, such as carvacrol (Sánchez et al., 2015), cinnamaldehyde (Fabra, Castro-Mayorga, et al., 2016), GTE (Falcó et al., 2018; Randazzo, Falcó, Aznar, \& Sánchez, 2017), and GSE (Joshi, Su, \& D'Souza, 2015; Su \& D'Souza, 2011; Su \& D'Souza, 2013), can be added to hydrocolloid matrices to confer them antiviral activity. In fact, Fabra et al. (in press) have recently reported, for the first time, the antiviral properties of alginate-lipid edible films containing GTE or GSE against MNV and HAV, GTE being more efficient than GSE (Fig. 1 and 2). 
731 It is worth mentioning that, in this particular case of antiviral edible coatings in which

732 the coating can be eaten, the dose is the most restrictive aspect since even though most

733 of the antimicrobial agents are GRAS, there are some limiting doses to avoid toxicity,

734 which is the case of essential oils (Bakkali, Averbeck, Averbeck, \& Idaomar, 2008).

735 According to EU legislation, edible coatings are included in the regulations for food 736 additives, which says "in order to protect human health, the safety of additives for use in

737 foods for human consumption must be assessed before they are placed on the 738 community market" so in the development of edible films and coatings, only additives

739 that appear in the community list of authorized substances can be used (EC 1331/208).

740 In addition, the ingredients used should not mislead consumers and sufficient

741 information (i.e., toxicity assays) is needed to confirm that the additive used is safe for 742 consumers (EU 234/2011).

743 In the US, edible coatings are considered a part of the food; as a consequence, their 744 ingredients must be declared on a label under the Food and Drug Administration (FDA). 745 In fact, the FDA provides a list that must be used as part of the coatings and emulsions. 746 This regulation permits the use of the listed components (mainly GRAS substances and 747 other safe ingredients) at certain concentrations (Aguirre-Joya et al., 2018; Franssen \& 748 Krochta, 2003). These authorized substances appear in the Title 21 "Food and Drugs," 749 Chapter I "Food and Drug Administration, Department of Health and Human Services" 750 in part 175 "Indirect Food Additives: Adhesives and Components of Coatings" (FDA, 751 2017). Furthermore, the US regulation also indicates that in the case of fruits and 752 vegetables, consumers must be informed about the food product composition (including 753 the coating ingredients).

\section{Encapsulation of antiviral compounds}


755

756

757

758

759

760

761

762

763

764

765

766

767

768

769

770

771

772

773

774

775

776

777

778

779

As previously mentioned, shellfish represents one of the most common food vehicles of viral contamination. Shellfish depuration is a commercial processing technology used worldwide, where shellfish are placed in tanks containing clean seawater and allowed to purge the contaminants for several days. Shellfish depuration rapidly removes bacterial pathogens, however the scientific community agrees on the inadequacy of commercial shellfish depuration processes for enteric viruses (McLeod et al., 2017). In this specific case, the incorporation of antiviral compounds within the water tanks is envisaged as the most promising approach. However, many natural antimicrobial compounds are sensitive molecules which can be affected by food processing conditions or interaction with food components, resulting in reduced antimicrobial effect. Micro- and nanoencapsulation processes, in which a compound is embedded within a protective matrix, have attracted increasing research interest for the protection of these sensitive compounds (Gómez-Mascaraque, Ambrosio-Martín, Fabra, Pérez-Masiá, \& LópezRubio; Gómez-Mascaraque \& Lopez-Rubio, 2016; Pérez-Masiá, Lagaron, \& LópezRubio, 2014). Many studies have focused on the development of micro- or nanoparticlebased systems for increased antimicrobial stability and activity but, to date, information about their potential use in food products is rather limited (Castro-Rosas et al., 2017). For instance, encapsulation of antimicrobial compounds has demonstrated to enhance their stability during food-processing treatments, such as electron beam irradiation (Gomes, Moreira, \& Castell-Perez, 2011), and the usefulness of these techniques to generate natural additives (Ko, Kim, \& Park, 2012) or to formulate antibacterial disinfectants (Krogsgard Nielsen et al., 2017). Similarly, encapsulation of antivirals for food applications has been scarcely explored. Recent developments in encapsulation of antiviral compounds include the use of chitosan to enhance the protection for (-)epigallocatechin gallate (EGCG, a green tea polyphenol) (Gómez-Mascaraque et al., 
2016) which was previously reported to be a very effective antiviral compound, reducing the titers of $\mathrm{HAV}$ and $\mathrm{MNV}$ in a dose-dependent manner at neutral $\mathrm{pH}$. Microencapsulated EGCG showed the potential to prolong the antiviral activity of EGCG against MNV via gradual bioactive release combined with its protection against degradation in simulated physiological conditions. Therefore, these results highlight the potential of encapsulated natural antiviral compounds to be used in food applications. For example, GSE and GTE have been successfully used as natural sanitizers of fresh produce and food contact surfaces (Falcó et al., 2018; Li et al., 2012; Randazzo et al., 2017; Su \& D'Souza, 2013), and encapsulation of these antiviral compounds may provide enhanced and prolonged antiviral activity as a consequence of the protection and more gradual release provided by the biopolymeric encapsulating matrices. In fact, different studies demonstrated the efficacy of alginate-based delivery particles to target shellfish tissues (Darmody et al., 2015; Prado-Alvarez et al., 2015), suggesting that encapsulation could represent a viable tool for the transport and delivery of antiviral compounds directly to the shellfish tissues.

\section{Final remarks}

Food contamination by human enteric viruses is a serious health and economic problem.

Currently, food manufacturing processes that may inactivate human enteric viruses cannot be applied without adversely affecting food quality. Therefore, the effective prevention of contamination, new food-processing strategies, new sanitation approaches, and consumer education could reduce enteric virus numbers and thereby decrease consumer risks of enteric virus infections. Among these strategies, one promising technology is the use of polymers and biopolymers with antiviral activity.

To evaluate the potential of polymers or biopolymers with antiviral activity, some publications have explored their efficacy against HAV and HuNoV, mainly using 
805 HuNoV surrogates. The use of different virus titers, inoculum-suspending matrices, and

806 virus-recovery procedures complicates comparisons among studies, as documented in

807 this review. Additionally, antiviral polymers have been mainly applied in in vitro

808 experiments with different levels of success.

809 The use of metals or metal nanoparticles to render antimicrobial polymeric materials has

810 significant potential applications. This is particularly the case in food contact and

811 packaging applications. However, there are still a number of issues, such as regulatory

812 issues and effectivity at low dosages that need to be better addressed and resolved for

813 this interesting technology to be widely used in industrial applications. The most

814 promising research is oriented toward the mastering of nanoparticles, which seems to

815 offer better stability, efficacy, and cost effectiveness.

816 Although there is increasing interest in the use of antimicrobial packaging and edible

817 coatings, motivated by the increasing consumer demand for safe and stable foods, little

818 information is available in the literature about how biopolymers could act as carriers of

819 antiviral compounds in real food samples. Therefore, the development of biopolymers

820 with antiviral activity and their applications in the food area is today an open field of

821 research that needs to be fully addressed.

822 Acknowledgments

823 This work was supported by the Spanish National Institute for Agriculture and Food

824 Research and Technology (INIA) co-financed by the European Social Fund (Project

825 RTA2014-00024-C03). MJF was supported by the "Ramon y Cajal" Young

826 Investigator.

827

828 Author Contributions 
829 Randazzo and Falcó researched prior studies, interpreted the results and drafted the

830 manuscript. Fabra compiled data and drafted the manuscript. López-Rubio and Sánchez

831 conceived the original idea and drafted the manuscript. All authors contributed to the

832 final manuscript. 
Table 1. Active packaging and food contact surfaces with virucidal activity.

\begin{tabular}{|c|c|c|c|c|c|c|c|}
\hline $\begin{array}{l}\text { (Potential) } \\
\text { Application }\end{array}$ & Active compound & $\begin{array}{l}\text { Type of polymer or } \\
\text { biopolymer }\end{array}$ & Virus & $\begin{array}{l}\text { Concentration of } \\
\text { the active } \\
\text { compound }\end{array}$ & Test conditions & $\begin{array}{l}\text { Inactivation } \\
\text { (log } \\
\text { reduction) }\end{array}$ & Reference \\
\hline \multirow[t]{4}{*}{ Active packaging } & Green seed extract & Chitosan & MNV & $5 ; 10 ; 15 \%$ & $23^{\circ} \mathrm{C}, 24 \mathrm{~h}$ & $\begin{array}{l}1.9 ; \quad 3.2 \\
>4.0\end{array}$ & (Amankwaah, 2013) \\
\hline & Green tea extract & Chitosan & MNV & $5 ; 10 ; 15 \%$ & $23^{\circ} \mathrm{C}, 24 \mathrm{~h}$ & $\begin{array}{l}1.6 ; \quad 4.5 ; \\
>4.5\end{array}$ & (Amankwaah, 2013) \\
\hline & \multirow[t]{2}{*}{ Cinnamaldehyde } & \multirow[t]{2}{*}{ PHB } & MNV & \multirow[t]{2}{*}{$2.60 \mathrm{mg} / \mathrm{cm}^{2}$} & \multirow[t]{2}{*}{$37^{\circ} \mathrm{C}, \mathrm{ON}, 100 \% \mathrm{RH}$} & 2.7 & \multirow{2}{*}{$\begin{array}{l}\text { (Fabra, Castro-Mayorga, et } \\
\text { al., 2016) }\end{array}$} \\
\hline & & & FCV & & & $<\mathrm{LOD}$ & \\
\hline \multirow{3}{*}{$\begin{array}{l}\text { Active packaging } \\
\text { and food contact } \\
\text { surfaces }\end{array}$} & Silver ions & PLA & FCV & $0.1 ; 1 \%$ & $24^{\circ} \mathrm{C}, 24 \mathrm{~h}$ & $2 ;>4.4$ & (Martínez-Abad et al., 2013) \\
\hline & \multirow{2}{*}{$\begin{array}{l}\text { Silver } \\
\text { nanoparticles }\end{array}$} & \multirow[t]{2}{*}{ PHBV } & $\mathrm{MNV}$ & \multirow[t]{2}{*}{$0.027 \%$} & \multirow[t]{2}{*}{$37^{\circ} \mathrm{C}, 24 \mathrm{~h}$} & 0.86 & \multirow{2}{*}{$\begin{array}{l}\text { (Castro-Mayorga et al., } \\
\text { 2017) }\end{array}$} \\
\hline & & & FCV & & & $<\mathrm{LOD}$ & \\
\hline \multirow[t]{6}{*}{$\begin{array}{ll}\text { Food } & \text { contact } \\
\text { surfaces } & \end{array}$} & Silver ions & $\begin{array}{l}\text { Plastic coupons } \\
\text { impregnated with zeolite } \\
\text { powder }\end{array}$ & FCV & $0.00035 \%$ & $23^{\circ} \mathrm{C}, 24 \mathrm{~h}$ & 5 & (Bright et al., 2008) \\
\hline & \multirow{2}{*}{$\begin{array}{l}\text { Silver } \\
\text { nanoparticles }\end{array}$} & \multirow{2}{*}{ Magnetic hybrid colloid } & $\varphi \mathrm{X} 174$ & \multirow[t]{2}{*}{$0.04 \%$} & \multirow[t]{2}{*}{$25^{\circ} \mathrm{C}, 1 \mathrm{~h}$} & $>2$ & \multirow[t]{2}{*}{ (Park et al., 2014) } \\
\hline & & & $\mathrm{MNV}$ & & & $>2$ & \\
\hline & Copper & $\mathrm{PHBV}^{1}$ & MNV & $0.05 \%$ & $25^{\circ} \mathrm{C}, 24 \mathrm{~h}, 100 \% \mathrm{RH}$ & 3.19 & $\begin{array}{lll}\text { (Castro-Mayorga et al., } \\
\text { 2018) }\end{array}$ \\
\hline & Copper & \multirow[t]{2}{*}{ Copper surfaces } & MNV & $89 \%$ & $\mathrm{RT}, 30 \mathrm{~min}$ & 5 & (Warnes et al., 2015) \\
\hline & Copper & & HuNoV GII.4 & $100 \%$ & $\mathrm{RT}, 1 \mathrm{~h}$ & 4 & (Manuel et al., 2015) \\
\hline
\end{tabular}

Abbreviation: PHB, Polyhydroxybutyrate; PHBV, 3-hydroxybutyrate-co-3-hydroxyvalerate;

PLA, Polylactide; LOD, limit of detection. 
Figure 1. Diagram of the methods used for assessing the antiviral activity of food-grade polymers or biopolymers.

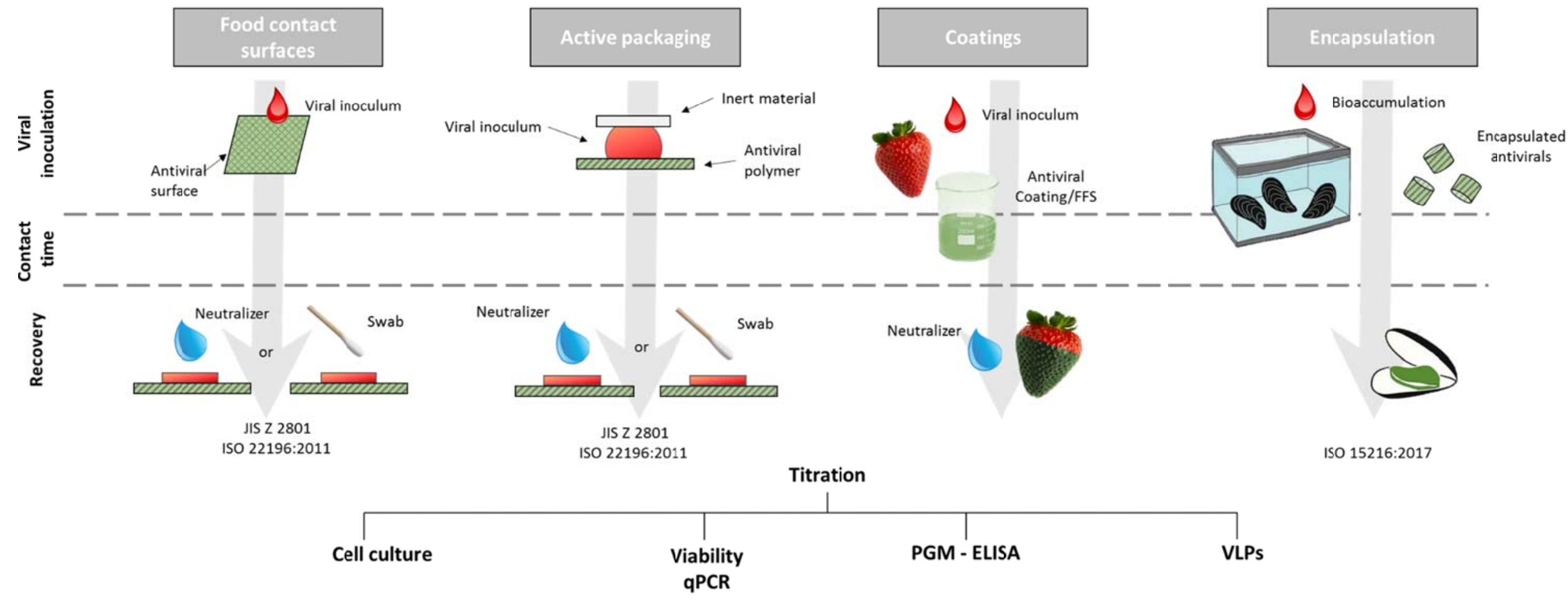


Figure 2. Food application of polymers and biopolymers with antiviral activity.

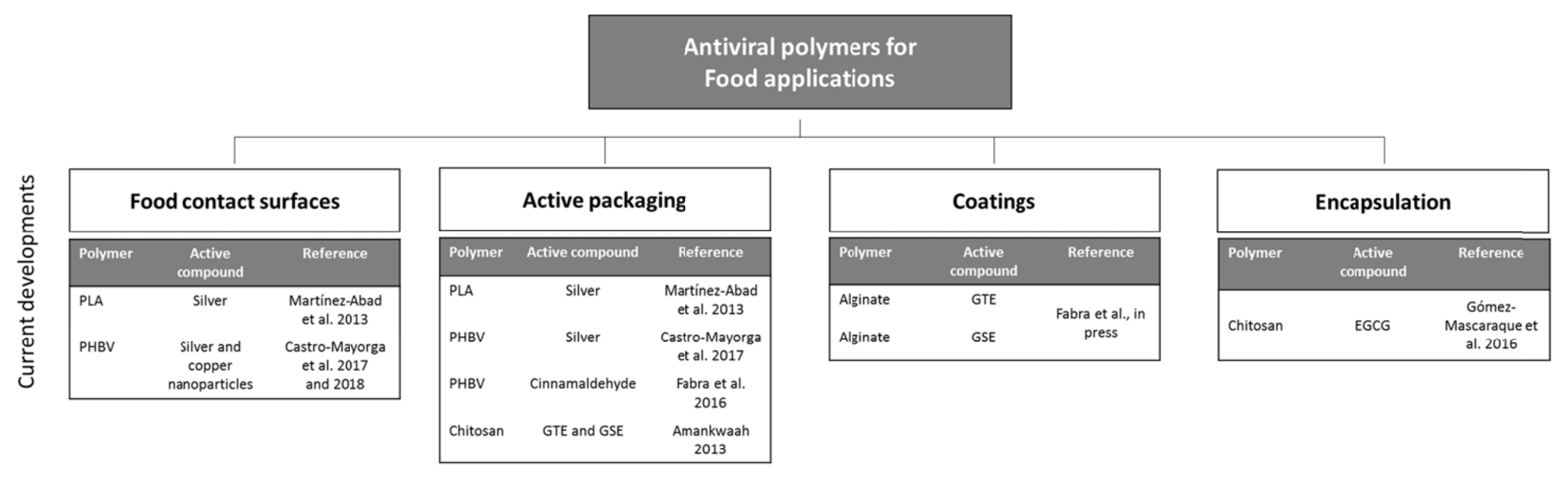

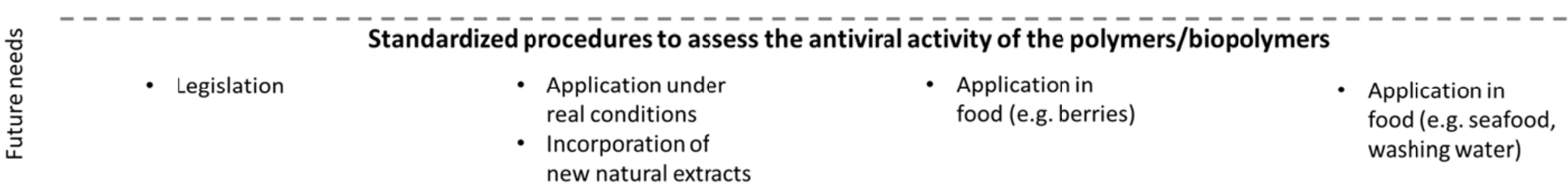




\section{References}

Abad, F. X., Villena, C., Guix, S., Caballero, S., Pintó, R. M., \& Bosch, A. (2001). Potential role of fomites in the vehicular transmission of human Astroviruses. Applied and Environmental Microbiology, 67(9), 3904-3907. doi:10.1128/AEM.67.9.39043907.2001

Aguirre-Joya, J. A., De Leon-Zapata, M. A., Alvarez-Perez, O. B., Torres-León, C., Nieto-Oropeza, D. E., Ventura-Sobrevilla, J. M., Aguilar, M. A., Ruelas-Chacón, X., Rojas, R., RamosAguiñaga, M. E., \& Aguilar, C. N. (2018). Chapter 1 - Basic and applied concepts of edible packaging for foods A2 - Grumezescu, Alexandru Mihai. In A. M. Holban (Ed.), Food Packaging and Preservation (pp. 1-61): Academic Press.

Ahmadi, A., Zorofchian Moghadamtousi, S., Abubakar, S., \& Zandi, K. (2015). Antiviral potential of algae polysaccharides isolated from marine sources: a review. BioMed Research International, 2015, 10. doi:10.1155/2015/825203

Akrami, F., Rodríguez-Lafuente, A., Bentayeb, K., Pezo, D., Ghalebi, S. R., \& Nerín, C. (2015). Antioxidant and antimicrobial active paper based on Zataria (Zataria multiflora) and two cumin cultivars (Cuminum cyminum). LWT - Food Science and Technology, 60(2, Part 1), 929-933. doi:https://doi.org/10.1016/j.Iwt.2014.09.051

Aloui, H., \& Khwaldia, K. (2016). Natural antimicrobial edible coatings for microbial safety and food quality enhancement. Comprehensive Reviews in Food Science and Food Safety, 15(6), 1080-1103. doi:10.1111/1541-4337.12226

Amankwaah, C. (2013). Incorporation of selected plant extracts into edible chitosan films and the effect on the antiviral, antibacterial and mechanical properties of the material. (PhD), The Ohio State University, Retrieved from https://etd.ohiolink.edu/ap/10?0::NO:10:P10 ACCESSION NUM:osu1366220367

Appendini, P., \& Hotchkiss, J. H. (2002). Review of antimicrobial food packaging. Innovative Food Science \& Emerging Technologies, 3(2), 113-126. doi:https://doi.org/10.1016/S1466-8564(02)00012-7

Arens, M., \& Travis, S. (2000). Zinc salts inactivate clinical isolates of herpes simplex virus in vitro. Journal of Clinical Microbiology, 38(5), 1758-1762.

Atmar, R. L., Opekun, A. R., Gilger, M. A., Estes, M. K., Crawford, S. E., Neill, F. H., Ramani, S., Hill, H., Ferreira, J., \& Graham, D. Y. (2014). Determination of the $50 \%$ human infectious dose for norwalk virus. Journal of Infectious Diseases, 209(7), 1016-1022. doi:10.1093/infdis/jit620

Bae, J., \& Schwab, K. J. (2008). Evaluation of Murine Norovirus, Feline Calicivirus, Poliovirus, and MS2 as surrogates for human norovirus in a model of viral persistence in surface water and groundwater. Applied and Environmental Microbiology, 74(2), 477-484. doi:10.1128/AEM.02095-06

Bakkali, F., Averbeck, S., Averbeck, D., \& Idaomar, M. (2008). Biological effects of essential oils - A review. Food and Chemical Toxicology, 46(2), 446-475. doi:https://doi.org/10.1016/j.fct.2007.09.106

Bermudez-Oria, A., Rodriguez-Gutierrez, G., Vioque, B., Rubio-Senent, F., \& FernandezBolanos, J. (2017). Physical and functional properties of pectin-fish gelatin films containing the olive phenols hydroxytyrosol and 3,4-dihydroxyphenylglycol. Carbohydrate Polymers, 178, 368-377. doi:10.1016/j.carbpol.2017.09.042

Boone, S. A., \& Gerba, C. P. (2007). Significance of fomites in the spread of respiratory and enteric viral disease. Applied and Environmental Microbiology, 73(6), 1687-1696. doi:10.1128/aem.02051-06

Borkow, G., \& Gabbay, J. (2004). Putting copper into action: copper-impregnated products with potent biocidal activities. Faseb Journal, 18(14), 1728-1730. doi:10.1096/fj.042029fje 
Bosquez-Molina, E., Jesús, E. R.-d., Bautista-Baños, S., Verde-Calvo, J. R., \& Morales-López, J. (2010). Inhibitory effect of essential oils against Colletotrichum gloeosporioides and Rhizopus stolonifer in stored papaya fruit and their possible application in coatings. Postharvest Biology and Technology, 57(2), 132-137. doi:https://doi.org/10.1016/j.postharvbio.2010.03.008

Brandelli, A., Brum, L. F. W., \& dos Santos, J. H. Z. (2017). Nanostructured bioactive compounds for ecological food packaging. Environmental Chemistry Letters, 15(2), 193-204. doi:10.1007/s10311-017-0621-7

Bright, K. R., Sicairos-Ruelas, E. E., Gundy, P. M., \& Gerba, C. P. (2008). Assessment of the antiviral properties of zeolites containing metal lons. Food and Environmental Virology, 1(1), 37. doi:10.1007/s12560-008-9006-1

Broglie, J. J., Alston, B., Yang, C., Ma, L., Adcock, A. F., Chen, W., \& Yang, L. (2015). Antiviral activity of gold/copper sulfide core/shell nanoparticles against human norovirus viruslike particles. PLoS One, 10(10), e0141050. doi:10.1371/journal.pone.0141050

Campos, C. A., Gerschenson, L. N., \& Flores, S. K. (2011). Development of edible films and coatings with antimicrobial activity. Food and Bioprocess Technology, 4(6), 849-875. doi:10.1007/s11947-010-0434-1

Cardoso, L. G., Pereira Santos, J. C., Camilloto, G. P., Miranda, A. L., Druzian, J. I., \& Guimarães, A. G. (2017). Development of active films poly (butylene adipate co-terephthalate) PBAT incorporated with oregano essential oil and application in fish fillet preservation. Industrial Crops and Products, 108, 388-397. doi:https://doi.org/10.1016/i.indcrop.2017.06.058

Carmona-Vicente, N., Allen, D. J., Rodríguez-Díaz, J., Iturriza-Gómara, M., \& Buesa, J. (2016). Antibodies against Lewis antigens inhibit the binding of human norovirus Gll.4 viruslike particles to saliva but not to intestinal Caco-2 cells. Virology Journal, 13(1). doi:10.1186/s12985-016-0538-y

Carmona-Vicente, N., Vila-Vicent, S., Allen, D., Gozalbo-Rovira, R., Iturriza-Gómara, M., Buesa, J., \& Rodríguez-Díaz, J. (2016). Characterization of a novel conformational Gll.4 norovirus epitope: Implications for norovirus-host interactions. Journal of Virology, 90(17), 7703-7714. doi:10.1128/JVI.01023-16

Castro-Mayorga, J. L., Fabra, M. J., \& Lagaron, J. M. (2016). Stabilized nanosilver based antimicrobial poly(3-hydroxybutyrate-co-3-hydroxyvalerate) nanocomposites of interest in active food packaging. Innovative Food Science and Emerging Technologies, 33, 524-533. doi:10.1016/j.ifset.2015.10.019

Castro-Mayorga, J. L., Fabra Rovira, M. J., Cabedo Mas, L., Sánchez Moragas, G., \& Lagarón Cabello, J. M. (2018). Antimicrobial nanocomposites and electrospun coatings based on poly(3-hydroxybutyrate-co-3-hydroxyvalerate) and copper oxide nanoparticles for active packaging and coating applications. Journal of Applied Polymer Science, 135(2). doi:10.1002/app.45673

Castro-Mayorga, J. L., Randazzo, W., Fabra, M. J., Lagaron, J. M., Aznar, R., \& Sánchez, G. (2017). Antiviral properties of silver nanoparticles against norovirus surrogates and their efficacy in coated polyhydroxyalkanoates systems. $L W T$ - Food Science and Technology, 79, 503-510. doi:10.1016/j.Iwt.2017.01.065

Castro-Rosas, J., Ferreira-Grosso, C. R., Gómez-Aldapa, C. A., Rangel-Vargas, E., RodríguezMarín, M. L., Guzmán-Ortiz, F. A., \& Falfan-Cortes, R. N. (2017). Recent advances in microencapsulation of natural sources of antimicrobial compounds used in food - A review. Food Research International, 102, 575-587. doi:https://doi.org/10.1016/i.foodres.2017.09.054

Chalier, P., Ben Arfa, A., Guillard, V., \& Gontard, N. (2009). Moisture and temperature triggered release of a volatile active agent from soy protein coated paper: effect of glass transition phenomena on carvacrol diffusion coefficient. Journal of Agricultural and Food Chemistry, 57(2), 658-665. doi:10.1021/jf802254p 
Cheesbrough, J. S., Green, J., Gallimore, C. I., Wright, P. A., \& Brown, D. W. (2000). Widespread environmental contamination with Norwalk-like viruses (NLV) detected in a prolonged hotel outbreak of gastroenteritis. Epidemiology and Infection, 125(1), 93-98.

Chen, M., Wang, Z.-W., Hu, C.-Y., \& Wang, J.-L. (2012). Effects of temperature on release of eugenol and isoeugenol from soy protein isolate films into simulated fatty food. Packaging Technology and Science, 25(8), 485-492. doi:10.1002/pts.995

Chirkov, S. N. (2002). The antiviral activity of chitosan (Review). Applied Biochemistry and Microbiology, 38(1), 1-8. doi:10.1023/A:1013206517442

Codex Alimentarius, Codex Committee on Food Hygiene. CAC/GL 79-2012. Guidelines on the application of general principles of food hygiene to the control of viruses in food.

D'Souza, D. H. (2014). Phytocompounds for the control of human enteric viruses. Current Opinion in Virology, 4, 44-49. doi:10.1016/j.coviro.2013.12.006

Dancho, B. A., Chen, H., \& Kingsley, D. H. (2012). Discrimination between infectious and noninfectious human norovirus using porcine gastric mucin. International Journal of Food Microbiology, 155(3), 222-226. doi:10.1016/j.ijfoodmicro.2012.02.010

Darmody, G., Maloy, A. P., Lynch, S. A., Prado-Alvarez, M., Cotterill, J., Wontner-Smith, T., \& Culloty, S. C. (2015). Tissue targeting of the European flat oyster, Ostrea edulis, using microencapsulated microbeads as a biological proxy. Aquaculture International, 23(2), 647-659. doi:10.1007/s10499-014-9842-y

Davis, R., Zivanovic, S., D'Souza, D. H., \& Davidson, P. M. (2012). Effectiveness of chitosan on the inactivation of enteric viral surrogates. Food Microbiology, 32(1), 57-62. doi:https://doi.org/10.1016/i.fm.2012.04.008

Davis, R., Zivanovic, S., Davidson, P. M., \& D'Souza, D. H. (2015). Enteric viral surrogate reduction by chitosan. Food and Environmental Virology, 7(4), 359-365. doi:10.1007/s12560-015-9208-2

de Graaf, M., van Beek, J., \& Koopmans, M. P. (2016). Human norovirus transmission and evolution in a changing world. Nature Reviews Microbiology, 14(7), 421-433. doi:10.1038/nrmicro.2016.48

Dehghani, S., Hosseini, S. V., \& Regenstein, J. M. (2018). Edible films and coatings in seafood preservation: A review. Food Chemistry, 240, 505-513. doi:https://doi.org/10.1016/j.foodchem.2017.07.034

DiCaprio, E. (2017). Recent advances in human norovirus detection and cultivation methods. Current Opinion in Food Science, 14, 93-97. doi:https://doi.org/10.1016/i.cofs.2017.02.007

DiCaprio, E., Phantkankum, N., Culbertson, D., Ma, Y., Hughes, J. H., Kingsley, D., Uribe, R. M., \& Li, J. (2016). Inactivation of human norovirus and Tulane virus in simple media and fresh whole strawberries by ionizing radiation. International Journal of Food Microbiology, 232, 43-51. doi:http://dx.doi.org/10.1016/j.ijfoodmicro.2016.05.013

Ditta, I. B., Steele, A., Liptrot, C., Tobin, J., Tyler, H., Yates, H. M., Sheel, D. W., \& Foster, H. A. (2008). Photocatalytic antimicrobial activity of thin surface films of TiO(2), CuO and TiO (2)/CuO dual layers on Escherichia coli and bacteriophage T4. Applied Microbiology and Biotechnology, 79(1), 127-133. doi:10.1007/s00253-008-1411-8

Donsì, F., Annunziata, M., Sessa, M., \& Ferrari, G. (2011). Nanoencapsulation of essential oils to enhance their antimicrobial activity in foods. LWT - Food Science and Technology, 44(9), 1908-1914. doi:https://doi.org/10.1016/j.Iwt.2011.03.003

Efrati, R., Natan, M., Pelah, A., Haberer, A., Banin, E., Dotan, A., \& Ophir, A. (2014). The effect of polyethylene crystallinity and polarity on thermal stability and controlled release of essential oils in antimicrobial films. Journal of Applied Polymer Science, 131(11), n/an/a. doi:10.1002/app.40309

EFSA. (2006). Opinion of the Scientific Panel on food additives, flavourings, processing aids and materials in contact with food (AFC) related to the 12th list of substances for food contact materials. EFSA Journal, 4(10), 395-n/a. doi:10.2903/j.efsa.2006.395 
EFSA. (2011a). Efsa Panel on Biological Hazards. Scientific Opinion on an update on the present knowledge on the occurrence and control of foodborne viruses. EFSA Journal, 9(7), 2190-n/a. doi:10.2903/j.efsa.2011.2190

EFSA. (2011b). Scientific Committee. Guidance on the risk assessment of the application of nanoscience and nanotechnologies in the food and feed chain. EFSA Journal, 9(5), 2140-n/a. doi:10.2903/j.efsa.2011.2140

EFSA. (2015). The European Union summary report on trends and sources of zoonoses, zoonotic agents and food-borne outbreaks in 2014. EFSA Journal, 13(12).

EFSA. (2016). The European Union summary report on trends and sources of zoonoses, zoonotic agents and food-borne outbreaks in 2015. EFSA Journal, 14(12).

EFSA. (2017). Efsa Panel on Biological Hazards. Public health risks associated with hepatitis E virus (HEV) as a food-borne pathogen. EFSA Journal, 15(7), e04886-n/a. doi:10.2903/j.efsa.2017.4886

Elizaquível, P., Azizkhani, M., Aznar, R., \& Sánchez, G. (2013). The effect of essential oils on norovirus surrogates. Food Control, 32(1), 275-278.

doi:10.1016/j.foodcont.2012.11.031

Elizaquível, P., Aznar, R., \& Sánchez, G. (2014). Recent developments in the use of viability dyes and quantitative PCR in the food microbiology field. Journal of Applied Microbiology, 116(1), 1-13. doi:10.1111/jam.12365

Ethelberg, S., Lisby, M., Bottiger, B., Schultz, A. C., Villif, A., Jensen, T., Olsen, K. E., Scheutz, F., Kjelso, C., \& Muller, L. (2010). Outbreaks of gastroenteritis linked to lettuce, Denmark, January 2010. Euro Surveillance, 15(6).

Ettayebi, K., Crawford, S. E., Murakami, K., Broughman, J. R., Karandikar, U., Tenge, V. R., Neill, F. H., Blutt, S. E., Zeng, X. L., Qu, L., Kou, B., Opekun, A. R., Burrin, D., Graham, D. Y., Ramani, S., Atmar, R. L., \& Estes, M. K. (2016). Replication of human noroviruses in stem cell-derived human enteroids. Science, 353(6306), 1387-1393. doi:10.1126/science.aaf5211

EU Commission (2011). Regulation on plastic materials and articles intended to come into contact with food (10/2011).

Fabra, M. J., Busolo, M. A., Lopez-Rubio, A., \& Lagaron, J. M. (2013). Nanostructured biolayers in food packaging. Trends in Food Science and Technology, 31(1), 79-87. doi:10.1016/j.tifs.2013.01.004

Fabra, M. J., Castro-Mayorga, J., Randazzo, W., Lagarón, J., López-Rubio, A., Aznar, R., \& Sánchez, G. (2016). Efficacy of cinnamaldehyde against enteric viruses and its activity after incorporation into biodegradable multilayer systems of interest in food packaging. Food and Environmental Virology, 8(2), 125-132.

Fabra, M. J., Falcó, I., Randazzo, W., Sánchez, G., \& López, A. (in press). Antiviral and antioxidant properties of active alginate edible films containing phenolic extracts. Food Hydrocolloids. doi:10.1016/j.foodhyd.2018.02.026

Fabra, M. J., Flores-López, M. L., Cerqueira, M. A., de Rodriguez, D. J., Lagaron, J. M., \& Vicente, A. A. (2016). Layer-by-layer technique to developing functional nanolaminate films with antifungal activity. Food and Bioprocess Technology, 9(3), 471-480. doi:10.1007/s11947-015-1646-1

Falcó, I., Randazzo, W., Gómez-Mascaraque, L., Aznar, R., López-Rubio, A., \& Sánchez, G. (2017). Effect of (-)-epigallocatechin gallate at different $\mathrm{pH}$ conditions on enteric viruses. LWT - Food Science and Technology. doi:10.1016/j.Iwt.2017.03.050

Falcó, I., Randazzo, W., Gómez-Mascaraque, L. G., Aznar, R., López-Rubio, A., \& Sánchez, G. (2018). Fostering the antiviral activity of green tea extract for sanitizing purposes through controlled storage conditions. Food Control, 84, 485-492. doi:https://doi.org/10.1016/i.foodcont.2017.08.037 
Falcó, I., Randazzo, W., Rodríguez-Díaz, J., Gozalbo-Rovira, R., Luque, D., Aznar, R., \& Sánchez, G. (under review). Evaluation of the antiviral activity of green tea extract in model food systems and under gastric conditions.

FDA (2010). Part 172.167. Listing of Food Additive Status: Silver Nitrate.

FDA (2017). Title 21: Food and Drugs. Part 175.105 to 175.390. Indirect food additives: adhesives and components of coatings.

Fernández-Pan, I., Maté, J. I., Gardrat, C., \& Coma, V. (2015). Effect of chitosan molecular weight on the antimicrobial activity and release rate of carvacrol-enriched films. Food Hydrocolloids, 51, 60-68. doi:https://doi.org/10.1016/j.foodhyd.2015.04.033

Franssen, L. R., \& Krochta, J. M. (2003). Edible coatings containing natural antimicrobials for processed foods. In Natural Antimicrobials for the Minimal Processing of Foods (pp. 250-262).

Friedman, M., \& Juneja, V. K. (2010). Review of antimicrobial and antioxidative activities of chitosans in food. Journal of Food Protection, 73(9), 1737-1761.

Gherardi, R., Becerril, R., Nerin, C., \& Bosetti, O. (2016). Development of a multilayer antimicrobial packaging material for tomato puree using an innovative technology. LWT - Food Science and Technology, 72, 361-367. doi:https://doi.org/10.1016/j.Iwt.2016.04.063

Gomes, C., Moreira, R. G., \& Castell-Perez, E. (2011). Microencapsulated antimicrobial compounds as a means to enhance electron beam irradiation treatment for inactivation of pathogens on fresh spinach leaves. Journal of Food Science, 76(6), E479488. doi:10.1111/j.1750-3841.2011.02264.x

Gómez-Mascaraque, L. G., Ambrosio-Martín, J., Fabra, M. J., Pérez-Masiá, R., \& López-Rubio, A. Novel nanoencapsulation structures for functional foods and nutraceutical applications. In S. Shampa \& P. Yashwant (Eds.), Nanotechnology in Nutraceuticals: Production to Consumption (Vol. 20, pp. 375-398). Boca Raton, FL, USA: Taylor \& Francis Group LLC. .

Gómez-Mascaraque, L. G., \& Lopez-Rubio, A. (2016). Protein-based emulsion electrosprayed micro- and submicroparticles for the encapsulation and stabilization of thermosensitive hydrophobic bioactives. Journal of Colloid and Interface Science, 465, 259-270. doi:10.1016/j.jcis.2015.11.061

Gómez-Mascaraque, L. G., Sánchez, G., \& Lopez-Rubio, A. (2016). Impact of molecular weight on the formation of electrosprayed chitosan microcapsules as delivery vehicles for bioactive compounds. Carbohydrate Polymers, 150, 121-130. doi:10.1016/j.carbpol.2016.05.012

Goyal, S. M., \& Cannon, J. L. (2016). Viruses in Foods: Springer International Publishing.

Guo, M., Yadav, M. P., \& Jin, T. Z. (2017). Antimicrobial edible coatings and films from microemulsions and their food applications. International Journal of Food Microbiology, 263, 9-16. doi:10.1016/j.ijfoodmicro.2017.10.002

Haldar, J., An, D., Álvarez de Cienfuegos, L., Chen, J., \& Klibanov, A. M. (2006). Polymeric coatings that inactivate both influenza virus and pathogenic bacteria. Proceedings of the National Academy of Sciences, 103(47), 17667-17671. doi:10.1073/pnas.0608803103

Hall, A. J., Wikswo, M. E., Pringle, K., Gould, L. H., \& Parashar, U. D. (2014). Vital signs: foodborne norovirus outbreaks-United States, 2009-2012. Morbidity and Mortality Weekly Report. Surveillance Summaries, 63(22), 491-495. doi:10.1007/s12560-0169235-7

Han, J., Castell-Perez, M. E., \& Moreira, R. G. (2008). Effect of food characteristics, storage conditions, and electron beam irradiation on active agent release from polyamidecoated LDPE films. Journal of Food Science, 73(2), E37-43. doi:10.1111/j.17503841.2007.00616.x 
Haraguchi, Y., Sakurai, H., Hussain, S., Anner, B. M., \& Hoshino, H. (1999). Inhibition of HIV-1 infection by zinc group metal compounds. Antiviral Research, 43(2), 123-133.

Hedlund, K. O., Rubilar-Abreu, E., \& Svensson, L. (2000). Epidemiology of calicivirus infections in Sweden, 1994-1998. Journal of Infectious Diseases, 181 Suppl 2, S275-280. doi:10.1086/315585

Hirneisen, K. A., \& Kniel, K. E. (2013). Comparing human norovirus surrogates: murine norovirus and Tulane virus. Journal of Food Protection, 76(1), 139-143. doi:10.4315/0362-028x.jfp-12-216

Honarvar, Z., Farhoodi, M., Khani, M. R., Mohammadi, A., Shokri, B., Ferdowsi, R., \& ShojaeeAliabadi, S. (2017). Application of cold plasma to develop carboxymethyl cellulosecoated polypropylene films containing essential oil. Carbohydrate Polymers, 176, 1-10. doi:10.1016/j.carbpol.2017.08.054

Hu, C.-Y., Chen, M., \& Wang, Z.-W. (2012). Release of thymol, cinnamaldehyde and vanillin from soy protein isolate films into olive oil. Packaging Technology and Science, 25(2), 97-106. doi:10.1002/pts.964

Hulisz, D. (2004). Efficacy of zinc against common cold viruses: an overview. Journal of the American Pharmacists Association, 44(5), 594-603.

Ilg, Y., \& Kreyenschmidt, J. (2011). Effects of food components on the antimicrobial activity of polypropylene surfaces containing silver ions (Ag+). International Journal of Food Science \& Technology, 46(7), 1469-1476. doi:10.1111/j.1365-2621.2011.02641.x

ISO 14476:2013. Chemical disinfectants and antiseptics. Quantitative suspension test for the evaluation of virucidal activity in the medical area. Test method and requirements (Phase 2/Step 1).

ISO 15216-1:2017. Microbiology of the food chain -- Horizontal method for determination of hepatitis A virus and norovirus using real-time RT-PCR -- Part 1: Method for quantification.

ISO 22196:2011. Measurement of antibacterial activity on plastics and other non-porous surfaces.

JIS Z 2801. Antibacterial products: Test for antibacterial activity and efficacy.

Joshi, S. S., Su, X., \& D'Souza, D. H. (2015). Antiviral effects of grape seed extract against feline calicivirus, murine norovirus, and hepatitis $A$ virus in model food systems and under gastric conditions. Food Microbiology, 52, 1-10. doi:10.1016/j.fm.2015.05.011

Kashiri, M., Cerisuelo, J. P., Domínguez, I., López-Carballo, G., Muriel-Gallet, V., Gavara, R., \& Hernández-Muñoz, P. (2017). Zein films and coatings as carriers and release systems of Zataria multiflora Boiss. essential oil for antimicrobial food packaging. Food Hydrocolloids, 70, 260-268. doi:https://doi.org/10.1016/j.foodhyd.2017.02.021

Kasuga, N. C., Yoshikawa, R., Sakai, Y., \& Nomiya, K. (2012). Syntheses, structures, and antimicrobial activities of remarkably light-stable and water-soluble silver complexes with amino acid derivatives, silver(I) N-acetylmethioninates. Inorganic Chemistry, 51(3), 1640-1647. doi:10.1021/ic201950p

Katz, E., \& Margalith, E. (1981). Inhibition of vaccinia virus maturation by zinc chloride. Antimicrobial Agents and Chemotherapy, 19(2), 213-217.

Kim, E.-J., Lee, Y.-D., Kim, K.-Y., \& Park, J.-H. (2015). A synergy effect of trisodium phosphate and ethanol on inactivation of Murine Norovirus 1 on lettuce and bell pepper. Journal of Microbiology and Biotechnology, 25(12), 2106-2109. doi:10.4014/jmb.1503.03032

Ko, J. A., Kim, W. Y., \& Park, H. J. (2012). Effects of microencapsulated Allyl isothiocyanate (AITC) on the extension of the shelf-life of Kimchi. International Journal of Food Microbiology, 153(1-2), 92-98. doi:10.1016/j.ijfoodmicro.2011.10.021

Kotwal, G., \& Cannon, J. L. (2014). Environmental persistence and transfer of enteric viruses. Current Opinion in Virology, 4(Supplement C), 37-43. doi:https://doi.org/10.1016/j.coviro.2013.12.003 
Krogsgard Nielsen, C., Kjems, J., Mygind, T., Snabe, T., Schwarz, K., Serfert, Y., \& Meyer, R. L. (2017). Antimicrobial effect of emulsion-encapsulated isoeugenol against biofilms of food pathogens and spoilage bacteria. International Journal of Food Microbiology, 242, 7-12. doi:10.1016/j.ijfoodmicro.2016.11.002

Kurek, M., Guinault, A., Voilley, A., Galić, K., \& Debeaufort, F. (2014). Effect of relative humidity on carvacrol release and permeation properties of chitosan based films and coatings. Food Chemistry, 144(Supplement C), 9-17. doi:https://doi.org/10.1016/j.foodchem.2012.11.132

Kuusi, M., Nuorti, J. P., Maunula, L., Minh Tran, N. N., Ratia, M., Karlsson, J., \& von Bonsdorff, C. H. (2002). A prolonged outbreak of Norwalk-like calicivirus (NLV) gastroenteritis in a rehabilitation centre due to environmental contamination. Epidemiology and Infection, 129(1), 133-138.

Lavin, D. M., Zhang, L., Furtado, S., Hopkins, R. A., \& Mathiowitz, E. (2013). Effects of protein molecular weight on the intrinsic material properties and release kinetics of wet spun polymeric microfiber delivery systems. Acta Biomaterialia, 9(1), 4569-4578. doi:10.1016/j.actbio.2012.08.005

Le Guyader, F. S., Mittelholzer, C., Haugarreau, L., Hedlund, K. O., Alsterlund, R., Pommepuy, M., \& Svensson, L. (2004). Detection of noroviruses in raspberries associated with a gastroenteritis outbreak. International Journal of Food Microbiology, 97(2), 179-186. doi:10.1016/j.ijfoodmicro.2004.04.018

Li, D., Baert, L., \& Uyttendaele, M. (2013). Inactivation of food-borne viruses using natural biochemical substances. Food Microbiology, 35(1), 1-9. doi:10.1016/j.fm.2013.02.009

Li, D., Baert, L., Zhang, D., Xia, M., Zhong, W., Van Coillie, E., Jiang, K., \& Uyttendaele, M. (2012). Effect of grape seed extract on human norovirus GII.4 and murine norovirus 1 in viral suspensions, on stainless steel discs, and in lettuce wash water. Applied and Environmental Microbiology, 78(21), 7572-7578. doi:10.1128/AEM.01987-12

López-Gálvez, F., Truchado, P., Sánchez, G., Aznar, R., Gil, M. I., \& Allende, A. (2016). Occurrence of enteric viruses in reclaimed and surface irrigation water: relationship with microbiological and physicochemical indicators. Journal of Applied Microbiology, 121(4), 1180-1188. doi:10.1111/jam.13224

López-Rubio, A., Almenar, E., Hernandez-Muñoz, P., Lagarón, J. M., Catalá, R., \& Gavara, R. (2004). Overview of active polymer-based packaging technologies for food applications. Food Reviews International, 20(4), 357-387. doi:10.1081/LFRI-200033462

López-Rubio, A., Gavara, R., \& Lagaron, J. M. (2006). Bioactive packaging: turning foods into healthier foods through biomaterials. Trends in Food Science \& Technology, 17(10), 567-575. doi:https://doi.org/10.1016/j.tifs.2006.04.012

Luzi, F., Fortunati, E., Jiménez, A., Puglia, D., Chiralt, A., \& Torre, L. (2017). PLA nanocomposites reinforced with cellulose nanocrystals from Posidonia Oceanica and ZnO nanoparticles for packaging application. Journal of Renewable Materials, 5(2), 103-115. doi:10.7569/JRM.2016.634135

Lynch, M. F., Tauxe, R. V., \& Hedberg, C. W. (2009). The growing burden of foodborne outbreaks due to contaminated fresh produce: risks and opportunities. Epidemiology and Infection, 137(3), 307-315. doi:10.1017/S0950268808001969

Maisanaba, S., Llana-Ruiz-Cabello, M., Gutiérrez-Praena, D., Pichardo, S., Puerto, M., Prieto, A. I., Jos, A., \& Cameán, A. M. (2017). New advances in active packaging incorporated with essential oils or their main components for food preservation. Food Reviews International, 33(5), 447-515. doi:10.1080/87559129.2016.1175010

Mantilla, N., Castell-Perez, M. E., Gomes, C., \& Moreira, R. G. (2013). Multilayered antimicrobial edible coating and its effect on quality and shelf-life of fresh-cut pineapple (Ananas comosus). LWT - Food Science and Technology, 51(1), 37-43. doi:https://doi.org/10.1016/j.Iwt.2012.10.010 
Manuel, C. S., Moore, M. D., \& Jaykus, L. A. (2015). Destruction of the capsid and genome of GII.4 Human Norovirus occurs during exposure to metal alloys containing copper. Applied and Environmental Microbiology, 81(15), 4940-4946. doi:10.1128/aem.0038815

Martínez-Abad, A., Ocio, M. J., Lagarón, J. M., \& Sánchez, G. (2013). Evaluation of silver-infused polylactide films for inactivation of Salmonella and feline calicivirus in vitro and on fresh-cut vegetables. International Journal of Food Microbiology, 162(1), 89-94. doi:10.1016/j.ijfoodmicro.2012.12.024

Mascheroni, E., Capretti, G., Limbo, S., \& Piergiovanni, L. (2012). Study of cellulose-lysozyme interactions aimed to a controlled release system for bioactives. Cellulose, 19(6), 18551866. doi:10.1007/s10570-012-9770-9

Mateo, E. M., Gomez, J. V., Dominguez, I., Gimeno-Adelantado, J. V., Mateo-Castro, R., Gavara, R., \& Jimenez, M. (2017). Impact of bioactive packaging systems based on EVOH films and essential oils in the control of aflatoxigenic fungi and aflatoxin production in maize. International Journal of Food Microbiology, 254, 36-46. doi:10.1016/j.ijfoodmicro.2017.05.007

Mauriello, G. (2016). Chapter 11 - Control of microbial activity using antimicrobial packaging A2 - Barros-Velázquez, Jorge. In Antimicrobial Food Packaging (pp. 141-152). San Diego: Academic Press.

McLeod, C., Polo, D., Le Saux, J. C., \& Le Guyader, F. S. (2017). Depuration and relaying: a review on potential removal of norovirus from oysters. Comprehensive Reviews in Food Science and Food Safety, 16(4), 692-706. doi:10.1111/1541-4337.12271

Moghimi, R., Aliahmadi, A., \& Rafati, H. (2017). Antibacterial hydroxypropyl methyl cellulose edible films containing nanoemulsions of Thymus daenensis essential oil for food packaging. Carbohydrate Polymers, 175, 241-248. doi:10.1016/j.carbpol.2017.07.086

Moreira, S. P., de Carvalho, W. M., Alexandrino, A. C., de Paula, H. C. B., Rodrigues, M. d. C. P., de Figueiredo, R. W., Maia, G. A., de Figueiredo, E. M. A. T., \& Brasil, I. M. (2014). Freshness retention of minimally processed melon using different packages and multilayered edible coating containing microencapsulated essential oil. International Journal of Food Science \& Technology, 49(10), 2192-2203. doi:10.1111/ijfs.12535

Moritz, M., \& Geszke-Moritz, M. (2013). The newest achievements in synthesis, immobilization and practical applications of antibacterial nanoparticles. Chemical Engineering Journal, 228, 596-613. doi:https://doi.org/10.1016/i.cej.2013.05.046

NACMCF. (2016). Response to the questions posed by the Food Safety and Inspection Service, the Centers for Disease Control and Prevention, the National Marine Fisheries Service, and the Defense Health Agency, Veterinary Services Activity regarding control strategies for reducing foodborne norovirus infections. Journal of Food Protection, 79(5), 843-889. doi:10.4315/0362-028X.JFP-15-215

Nappier, S. P., Graczyk, T. K., \& Schwab, K. J. (2008). Bioaccumulation, retention, and depuration of enteric viruses by Crassostrea virginica and Crassostrea ariakensis oysters. Applied and Environmental Microbiology, 74(22), 6825-6831. doi:10.1128/aem.01000-08

Narayanan, A., Neera, Mallesha, \& Ramana, K. V. (2013). Synergized antimicrobial activity of eugenol incorporated polyhydroxybutyrate films against food spoilage microorganisms in conjunction with pediocin. Applied Biochemistry and Biotechnology, 170(6), 13791388. doi:10.1007/s12010-013-0267-2

Ng, Y. C., Kim, Y. W., Ryu, S., Lee, A., Lee, J.-S., \& Song, M. J. (2017). Suppression of norovirus by natural phytochemicals from Aloe vera and Eriobotryae folium. Food Control, 73, 1362-1370. doi:https://doi.org/10.1016/j.foodcont.2016.10.051

Nguyen Van Long, N., Joly, C., \& Dantigny, P. (2016). Active packaging with antifungal activities. International Journal of Food Microbiology, 220, 73-90. doi:10.1016/j.ijfoodmicro.2016.01.001 
Noyce, J. O., Michels, H., \& Keevil, C. W. (2007). Inactivation of influenza A virus on copper versus stainless steel surfaces. Applied and Environmental Microbiology, 73(8), 27482750. doi:10.1128/aem.01139-06

Otero, V., Becerril, R., Santos, J. A., Rodríguez-Calleja, J. M., Nerín, C., \& García-López, M.-L. (2014). Evaluation of two antimicrobial packaging films against Escherichia coli 0157:H7 strains in vitro and during storage of a Spanish ripened sheep cheese (Zamorano). Food Control, 42, 296-302. doi:https://doi.org/10.1016/j.foodcont.2014.02.022

Pangestuti, R., \& Kim, S.-K. (2014). Chapter Seven - Biological activities of carrageenan. In S.-K. Kim (Ed.), Advances in Food and Nutrition Research (Vol. 72, pp. 113-124): Academic Press.

Park, H. H., Park, S., Ko, G., \& Woo, K. (2013). Magnetic hybrid colloids decorated with Ag nanoparticles bite away bacteria and chemisorb viruses. Journal of Materials Chemistry B, 1(21), 2701-2709. doi:10.1039/C3TB20311E

Park, S. Y., Park, H. H., Kim, S. Y., Kim, S. J., Woo, K., \& Ko, G. (2014). Antiviral properties of silver nanoparticles on a magnetic hybrid colloid. Applied and Environmental Microbiology, 80(8), 2343-2350. doi:10.1128/AEM.03427-13

Pérez-Masiá, R., Lagaron, J. M., \& López-Rubio, A. (2014). Development and optimization of novel encapsulation structures of interest in functional foods through electrospraying. Food and Bioprocess Technology, 7(11), 3236-3245. doi:10.1007/s11947-014-1304-z

Prado-Alvarez, M., Lynch, S. A., Kane, A., Darmody, G., Pardo, B. G., Martinez, P., Cotterill, J., Wontner-Smith, T., \& Culloty, S. C. (2015). Oral immunostimulation of the oyster Ostrea edulis: Impacts on the parasite Bonamia ostreae. Fish \& Shellfish Immunology, 45(1), 43-51. doi:10.1016/j.fsi.2015.01.019

Quintavalla, S., \& Vicini, L. (2002). Antimicrobial food packaging in meat industry. Meat Science, 62(3), 373-380. doi:https://doi.org/10.1016/S0309-1740(02)00121-3

Randazzo, W., Falcó, I., Aznar, R., \& Sánchez, G. (2017). Effect of green tea extract on enteric viruses and its application as natural sanitizer. Food Microbiology, 66, 150-156. doi:10.1016/j.fm.2017.04.018

Randazzo, W., Jiménez-Belenguer, A., Settanni, L., Perdones, A., Moschetti, M., Palazzolo, E., Guarrasi, V., Vargas, M., Germanà, M. A., \& Moschetti, G. (2016). Antilisterial effect of citrus essential oils and their performance in edible film formulations. Food Control, 59, 750-758. doi:10.1016/j.foodcont.2015.06.057

Randazzo, W., López-Gálvez, F., Allende, A., Aznar, R., \& Sánchez, G. (2016). Evaluation of viability PCR performance for assessing norovirus infectivity in fresh-cut vegetables and irrigation water. International Journal of Food Microbiology, 229, 1-6.

Requena, R., Jiménez, A., Vargas, M., \& Chiralt, A. (2016). Poly[(3-hydroxybutyrate)-co-(3hydroxyvalerate)] active bilayer films obtained by compression moulding and applying essential oils at the interface. Polymer International, 65(8), 883-891. doi:10.1002/pi.5091

Rezaeigolestani, M., Misaghi, A., Khanjari, A., Basti, A. A., Abdulkhani, A., \& Fayazfar, S. (2017). Antimicrobial evaluation of novel poly-lactic acid based nanocomposites incorporated with bioactive compounds in-vitro and in refrigerated vacuum-packed cooked sausages. International Journal of Food Microbiology, 260, 1-10. doi:https://doi.org/10.1016/j.ijfoodmicro.2017.08.006

Rodríguez-Lázaro, D., Cook, N., Ruggeri, F. M., Sellwood, J., Nasser, A., Nascimento, M. S. J., D'Agostino, M., Santos, R., Saiz, J. C., Rzeżutka, A., Bosch, A., Gironés, R., Carducci, A., Muscillo, M., Kovač, K., Diez-Valcarce, M., Vantarakis, A., von Bonsdorff, C.-H., de Roda Husman, A. M., Hernández, M., \& van der Poel, W. H. M. (2012). Virus hazards from food, water and other contaminated environments. FEMS Microbiology Reviews, 36(4), 786-814. doi:10.1111/j.1574-6976.2011.00306.x 
Rodríguez-Martínez, A. V., Sendón, R., Abad, M. J., González-Rodríguez, M. V., BarrosVelázquez, J., Aubourg, S. P., Paseiro-Losada, P., \& Rodríguez-Bernaldo de Quirós, A. (2016). Migration kinetics of sorbic acid from polylactic acid and seaweed based films into food simulants. LWT - Food Science and Technology, 65, 630-636. doi:https://doi.org/10.1016/j.Iwt.2015.08.029

Rönnqvist, M., Aho, E., Mikkelä, A., Ranta, J., Tuominen, P., Rättö, M., \& Maunula, L. (2014). Norovirus transmission between hands, gloves, utensils, and fresh produce during simulated food handling. Applied and Environmental Microbiology, 80(17), 5403-5410. doi:10.1128/AEM.01162-14

Russell, A. D. (2003). Similarities and differences in the responses of microorganisms to biocides. Journal of Antimicrobial Chemotherapy, 52(5), 750-763. doi:10.1093/jac/dkg422

Ryu, S., You, H. J., Kim, Y. W., Lee, A., Ko, G. P., Lee, S.-J., \& Song, M. J. (2015). Inactivation of norovirus and surrogates by natural phytochemicals and bioactive substances. Molecular Nutrition \& Food Research, 59(1), 65-74. doi:10.1002/mnfr.201400549

Sánchez-González, L., Cháfer, M., Hernández, M., Chiralt, A., \& González-Martínez, C. (2011). Antimicrobial activity of polysaccharide films containing essential oils. Food Control, 22(8), 1302-1310. doi:https://doi.org/10.1016/i.foodcont.2011.02.004

Sánchez, C., Aznar, R., \& Sánchez, G. (2015). The effect of carvacrol on enteric viruses. International Journal of Food Microbiology, 192, 72-76. doi:10.1016/j.ijfoodmicro.2014.09.028

Sánchez, G. (2015). Processing strategies to inactivate Hepatitis A virus in food products: a critical review. Comprehensive Reviews in Food Science and Food Safety, 14(6), 771784. doi:10.1111/1541-4337.12154

Sánchez, G., \& Aznar, R. (2015). Evaluation of natural compounds of plant origin for inactivation of enteric viruses. Food and Environmental Virology, 7(2), 183-187. doi:10.1007/s12560-015-9181-9

Sardarodiyan, M., \& Mahdian, E. (2016). Active packaging systems for a modern society. International Journal of PharmTech Research, 9(7), 357-363.

Seo, K., Lee, J. E., Lim, M. Y., \& Ko, G. (2012). Effect of temperature, pH, and $\mathrm{NaCl}$ on the inactivation kinetics of murine norovirus. Journal of Food Protection, 75(3), 533-540. doi:10.4315/0362-028X.JFP-11-199

Seyfarth, F., Schliemann, S., Elsner, P., \& Hipler, U. C. (2008). Antifungal effect of high- and lowmolecular-weight chitosan hydrochloride, carboxymethyl chitosan, chitosan oligosaccharide and N-acetyl-D-glucosamine against Candida albicans, Candida krusei and Candida glabrata. International Journal of Pharmaceutics, 353(1-2), 139-148. doi:10.1016/j.ijpharm.2007.11.029

Shah, M. P., Wikswo, M. E., Barclay, L., Kambhampati, A., Shioda, K., Parashar, U. D., Vinje, J., \& Hall, A. J. (2017). Near real-time surveillance of U.S. norovirus outbreaks by the Norovirus Sentinel Testing and Tracking Network - United States, August 2009-July 2015. Morbidity and Mortality Weekly Report, 66(7), 185-189. doi:10.15585/mmwr.mm6607a1

Sipahi, R. E., Castell-Perez, M. E., Moreira, R. G., Gomes, C., \& Castillo, A. (2013). Improved multilayered antimicrobial alginate-based edible coating extends the shelf life of freshcut watermelon (Citrullus lanatus). LWT - Food Science and Technology, 51(1), 9-15. doi:https://doi.org/10.1016/i.Iwt.2012.11.013

Su, Q. Z., Lin, Q. B., Chen, C. F., Wu, Y. M., Wu, L. B., Chen, X. Q., \& Wang, Z. W. (2015). Effect of antioxidants and light stabilisers on silver migration from nanosilver-polyethylene composite packaging films into food simulants. Food Additives \& Contaminants. Part A, 32(9), 1561-1566. doi:10.1080/19440049.2015.1075258 
Su, X., \& D'Souza, D. H. (2011). Grape seed extract for control of human enteric viruses. Applied and Environmental Microbiology, 77(12), 3982-3987. doi:10.1128/aem.0019311

Su, X., \& D'Souza, D. H. (2013). Grape seed extract for foodborne virus reduction on produce. Food Microbiology, 34(1), 1-6. doi:10.1016/j.fm.2012.10.006

Su, X., Zivanovic, S., \& D'Souza, D. H. (2009). Effect of chitosan on the infectivity of murine norovirus, feline calicivirus, and bacteriophage MS2. Journal of Food Protection, 72(12), 2623-2628.

Suara, R. O., \& Crowe, J. E., Jr. (2004). Effect of zinc salts on respiratory syncytial virus replication. Antimicrobial Agents and Chemotherapy, 48(3), 783-790.

Sung, S.-Y., Sin, L. T., Tee, T.-T., Bee, S.-T., Rahmat, A. R., Rahman, W. A. W. A., Tan, A.-C., \& Vikhraman, M. (2013). Antimicrobial agents for food packaging applications. Trends in Food Science \& Technology, 33(2), 110-123. doi:https://doi.org/10.1016/j.tifs.2013.08.001

Suppakul, P., Sonneveld, K., Bigger, S. W., \& Miltz, J. (2011). Diffusion of linalool and methylchavicol from polyethylene-based antimicrobial packaging films. LWT - Food Science and Technology, 44(9), 1888-1893. doi:https://doi.org/10.1016/i.lwt.2011.03.024

Tan, M., \& Jiang, X. (2005). Norovirus and its histo-blood group antigen receptors: An answer to a historical puzzle. Trends in Microbiology, 13(6), 285-293. doi:10.1016/j.tim.2005.04.004

Tang, Q., Li, D., Xu, J., Wang, J., Zhao, Y., Li, Z., \& Xue, C. (2010). Mechanism of inactivation of Murine Norovirus-1 by high pressure processing. International Journal of Food Microbiology, 137(2-3), 186-189. doi:10.1016/j.jfoodmicro.2009.10.033

Tawakkal, I. S. M. A., Cran, M. J., \& Bigger, S. W. (2016). Interaction and quantification of thymol in active PLA-based materials containing natural fibers. Journal of Applied Polymer Science, 133(2), n/a-n/a. doi:10.1002/app.42160

Teunis, P. F. M., Moe, C. L., Liu, P., Miller, S. E., Lindesmith, L., Baric, R. S., Le Pendu, J., \& Calderon, R. L. (2008). Norwalk virus: How infectious is it? Journal of Medical Virology, 80(8), 1468-1476. doi:10.1002/jmv.21237

Thomassin, J. M., Lenoir, S., Riga, J., Jerome, R., \& Detrembleur, C. (2007). Grafting of poly[2(tert-butylamino)ethyl methacrylate] onto polypropylene by reactive blending and antibacterial activity of the copolymer. Biomacromolecules, 8(4), 1171-1177. doi:10.1021/bm0611228

Tian, P., Brandi, M., \& Mandrell, R. (2005). Porcine gastric mucin binds to recombinant norovirus particles and competitively inhibits their binding to histo-blood group antigens and Caco-2 cells. Letters in Applied Microbiology, 41(4), 315-320. doi:10.1111/j.1472-765X.2005.01775.x

Torlak, E., \& Sert, D. (2013). Antibacterial effectiveness of chitosan-propolis coated polypropylene films against foodborne pathogens. International Journal of Biological Macromolecules, 60, 52-55. doi:10.1016/j.ijbiomac.2013.05.013

Umagiliyage, A. L., Becerra-Mora, N., Kohli, P., Fisher, D. J., \& Choudhary, R. (2017). Antimicrobial efficacy of liposomes containing $d$-limonene and its effect on the storage life of blueberries. Postharvest Biology and Technology, 128, 130-137. doi:https://doi.org/10.1016/i.postharvbio.2017.02.007

Umaraw, P., \& Verma, A. K. (2017). Comprehensive review on application of edible film on meat and meat products: An eco-friendly approach. Critical Reviews in Food Science and Nutrition, 57(6), 1270-1279. doi:10.1080/10408398.2014.986563

Warnes, S. L., Green, S. M., Michels, H. T., \& Keevil, C. W. (2010). Biocidal efficacy of copper alloys against pathogenic enterococci involves degradation of genomic and plasmid DNAs. Applied and Environmental Microbiology, 76(16), 5390-5401. doi:10.1128/aem.03050-09 
Warnes, S. L., \& Keevil, C. W. (2013). Inactivation of norovirus on dry copper alloy surfaces. PLoS One, 8(9), e75017. doi:10.1371/journal.pone.0075017

Warnes, S. L., Summersgill, E. N., \& Keevil, C. W. (2015). Inactivation of murine norovirus on a range of copper alloy surfaces is accompanied by loss of capsid integrity. Applied and Environmental Microbiology, 81(3), 1085-1091. doi:10.1128/aem.03280-14

WHO. (2015). WHO estimates of the global burden of foodborne diseases. Foodborne diseases burden epidemiology reference group 2007-2015. WHO Press.

Yildirim, S., Röcker, B., Pettersen, M. K., Nilsen-Nygaard, J., Ayhan, Z., Rutkaite, R., Radusin, T., Suminska, P., Marcos, B., \& Coma, V. (2018). Active packaging applications for food. Comprehensive Reviews in Food Science and Food Safety, 17(1), 165-199. doi:10.1111/1541-4337.12322

Yuan, G., Chen, X., \& Li, D. (2016). Chitosan films and coatings containing essential oils: The antioxidant and antimicrobial activity, and application in food systems. Food Research International, 89, 117-128. doi:https://doi.org/10.1016/j.foodres.2016.10.004 